Article

\title{
Traditional Uses of Medicinal Plants by Ethnic People in the Kavrepalanchok District, Central Nepal
}

\author{
Gabriele Ambu ${ }^{1}$, Ram Prasad Chaudhary ${ }^{2}$, Mauro Mariotti ${ }^{1}$ and Laura Cornara ${ }^{1, *}$ \\ 1 Department of Earth, Environment and Life Sciences, University of Genova, 16132 Genova, Italy; \\ frategabriele@libero.it (G.A.); m.mariotti@unige.it (M.M.) \\ 2 Research Centre for Applied Science and Technology (RECAST), Tribhuvan University, \\ 44613 Kathmandu, Nepal; ram.chaudhary53@gmail.com \\ * Correspondence: laura.cornara@unige.it or cornaral@gmail.com; Tel.: +39-010-209-9364
}

Received: 13 May 2020; Accepted: 15 June 2020; Published: 17 June 2020

check for updates

\begin{abstract}
In rural areas of Nepal, where it is difficult to get access to Government health care facilities, people depend on medicinal plants and local healers for health problems. This study concerns an ethnobotanical survey of the Kavrepalanchok District, reporting some unusual uses of medicinal plants and original recipes. A total of 32 informants were interviewed, 24 of them being key informants. Ethnobotanical uses concerned 116 taxa, of which 101 were medicinal plants, with the most representative species belonging to Asteraceae, Fabaceae, Lamiaceae, and Zingiberaceae. Ethnobotanical indexes were used to evaluate the ethnopharmacological importance of each plant species and the degree of agreement among the informants' knowledge. Informant consensus factor (Fic) showed that the fever category had the greatest agreement. Highest fidelity level (FL) values were found for Calotropis gigantea used for dermatological diseases, Drymaria cordata for fever, Mangifera indica and Wrightia arborea for gastrointestinal disorders. Data document the richness of the local flora and the traditional knowledge on medicinal plant species used by ethnic communities in rural areas. The active involvement of local populations in the conservation and management of medicinal plant species will encourage future projects for the sustainable development of the biological and cultural diversity of these rural areas of Nepal.
\end{abstract}

Keywords: traditional ecological knowledge; ethnopharmacology; medicinal plants; conservation

\section{Introduction}

Traditional systems of medicine are important health sources spread all over the world, especially in developing countries [1]. Most interesting ethnobotanical data can be generally collected in ethnic communities living in rural areas of remote regions, where Traditional Ethnobotanical Knowledge (TEK) remains often underdocumented without a proper documentation [2]. In such contexts it is pivotal to preserve the interaction between indigenous peoples and their environment to avoid that this knowledge fades out in a few generations. Accordingly, it appears increasingly important the role of TEK for promoting sustainable ecosystems and to develop strategies for protecting and enhancing the natural resources.

In Nepal, out of a total of approximately 28 million inhabitants, $80 \%$ lives in rural areas [3,4], where it is difficult to access government health care facilities. It is estimated that there are only 2 physicians per 10,000 people, while in other parts of the world the number is higher, e.g. in Europe there are on average 33 physicians per 10,000 people (minimum Romania 19, maximum Greece 54) [5]. After the earthquake $\left(8 \mathrm{M}_{\mathrm{W}}\right)$ in April 2015, access to medical care has became even more problematic and rural areas have been exposed to many epidemic diseases, especially among children and elderly people. Therefore, people in these areas depend highly on traditional use of medicinal 
plants for their primary health care. This traditional knowledge, passed down orally mainly within families or small groups of healers, includes folk, shamanistic and Ayurvedic medicine [6].

Due to its significant variations in altitude, topography and climate, Nepal has an important floral biodiversity with 6500 species of flowering plants and ferns [7] of which 2000 are commonly used in traditional healing practices [8]. Also there is a high diversity in ethnic groups (125), each of them with its own culture, language, religious rites, and traditional practices in the use of medicinal plants $[9,10]$.

The present study is an in-depth investigation of medicinal plants used by ethnic people residing in several villages of Kavrepalanchok District, which are located outside tourist circuits and characterized by a high rate of poverty. Our results integrate previous ethnobotanical studies conducted in this zone of Central Nepal [11-27], with a special focus on medicinal plants selected and used by local healers and shamans who are considered the depository of TEK. The data highlight most quoted species in the treatment of specific pathologies, as shown by ethnobotanical indexes. In addition, we have also recorded some unusual uses of medicinal plants and original recipes, as well as the use of species that have never been reported in previous ethnobotanical studies from Central Nepal. The valorisation of folk medicine can promote a sustainable development of the natural resources in these rural areas.

\section{Results}

A total of 32 informants ( 26 men and 6 women) aged between 23 and 81 years were interviewed (Table 1).

Table 1. Distribution of informants gender and age.

\begin{tabular}{ccccccc}
\hline \multirow{2}{*}{ Gender } & \multicolumn{5}{c}{ Number of Informants by Gender and Class of Age (Years) } \\
\cline { 2 - 7 } & $\mathbf{2 3 - 3 0}$ & $\mathbf{3 1 - 4 0}$ & $\mathbf{4 2 - 5 0}$ & $\mathbf{5 2 - 6 0}$ & $\mathbf{6 5 - 7 0}$ & $\mathbf{7 5}$ and $>\mathbf{7 5}$ \\
\hline Men & 2 & 7 & 4 & 3 & 7 & 3 \\
Women & 0 & 1 & 2 & 1 & 2 & 0 \\
Total & 2 & 8 & 6 & 4 & 9 & 3 \\
\hline
\end{tabular}

About 38\% were illiterate (12 informants), 34\% had a primary level of literacy (11 informants), about $25 \%$ a secondary level (8 informants) and only one informant (3\%) had a degree. Among them, 24 were selected as key informants as follows: 8 shamans (jhankris), 2 local healers, 14 farmers and plant traders. The interviewed shamans belonged to the Tamang ethnic group (one was a woman) and the local healers belonged to the Brahmin ethnic group and were experts in Ayurvedic medicine. These informants lived in remote areas and preserved old tradition. In our survey, ethnobotanical knowledge was concentrated among informants with primary education $(41 \%)$, followed by those with secondary education (33\%), and finally by those who had no educational level (22\%) while the only one graduate informant corresponded to $4 \%$ of the total. The 6 women provided $15 \%$ of the information collected.

\subsection{Plants Diversity}

The informants reported 318 ethnobotanical uses of 116 plants belonging to 57 families (Table 2). 
Table 2. Plants used by ethnic people in Kavrepalanchok District, Central Nepal.

\begin{tabular}{|c|c|c|c|c|c|c|c|}
\hline $\begin{array}{l}\text { Family Scientific Name } \\
\text { Voucher Number }\end{array}$ & Vernacular Name ${ }^{a}$ & Origin $^{b}$ & Parts Used ${ }^{\mathrm{c}}$ & Ethnobotanical Uses ${ }^{d}$ & Uses Description & $\begin{array}{c}\text { Similar Uses } \\
\text { References }\end{array}$ & Other Uses References \\
\hline \multicolumn{8}{|l|}{ Acanthaceae } \\
\hline $\begin{array}{l}\text { Justicia adhatoda L. } \\
\text { GA20171031NP011 }\end{array}$ & Asuro (N) Basak (T) & $\mathrm{W}$ & $\begin{array}{l}\mathrm{L} \\
\mathrm{R}\end{array}$ & $\begin{array}{l}\text { agr } \\
\text { med/resp,fev,urogen } \\
\text { med/fev }\end{array}$ & $\begin{array}{l}\text { The leaves are used in horticulture as fertilizer } \\
\text { Dried leaves are smoked to cure cough. Powder of } 4 \\
\text { dried leaves is mixed with honey (or water) and } \\
\text { eaten, twice a day (morning and evening), to treat } \\
\text { fever. } \\
\text { In case of urinary problems: } 3 \text { dry leaves, after being } \\
\text { left in water for } 5 \text { h, are cut into small pieces, honey } \\
\text { is added, and the final product is eaten. } \\
\text { Root juice is filtered and drunk } 3 \text { times a day to treat } \\
\text { high fever. }\end{array}$ & {$[23,24,26,27]$} & $\begin{array}{l}\text { Typhoid [23], rheumatic } \\
\text { pain [24], sinusitis [25] }\end{array}$ \\
\hline $\begin{array}{c}\text { Strobilanthes } \\
\text { pentastemonoides (Nees) T. } \\
\text { Anderson } \\
\text { (= Goldfussia } \\
\text { pentastemonoides Nees) } \\
\text { GA20181012NP052 }\end{array}$ & Gathe $(\mathrm{N})$ & $\mathrm{W}$ & $\mathrm{R}$ & $\mathrm{med} / \mathrm{fev}$ & $\begin{array}{l}\text { The root is cut into small pieces, pounded with } \\
\text { water and the filtered juice is drunk } 3 \text { times a day to } \\
\text { cure high fever. }\end{array}$ & & \\
\hline \multicolumn{8}{|l|}{ Amaranthaceae } \\
\hline $\begin{array}{l}\text { Achyranthes bidentata Blume } \\
\text { GA20171113NP047 }\end{array}$ & $\begin{array}{l}\text { Dok, Datiwan (N), } \\
\text { Ghyurupuchu, } \\
\text { Ghiughiuru (T) }\end{array}$ & $\mathrm{W}$ & $\begin{array}{c}\mathrm{R} \\
\mathrm{Wp}\end{array}$ & $\begin{array}{c}\mathrm{med} / \mathrm{fev} \\
\mathrm{med} / \mathrm{mat} \\
\mathrm{med} / \text { urogen } \\
\text { vet } \\
\text { med/met,fev,derm }\end{array}$ & $\begin{array}{l}\text { Root is crushed with water and the filtrate is drunk } \\
3 \text { times per a to cure fever and typhoid. One day of } \\
\text { treatment is often sufficient for healing. } \\
\text { Root juice is drunk } 2 \text { times day to promote } \\
\text { childbirth. } \\
\text { The juice obtained by squeezing the root is drunk to } \\
\text { treat urinary problems (blood in the urine). } \\
\text { Root juice stimulates lactation in buffaloes. } \\
\text { Plant juice is drunk for blood purification and to } \\
\text { cure fever. } \\
\text { The well-washed plant is rubbed directly on the } \\
\text { skin, to treat pimples, boils, itchy pustules. }\end{array}$ & {$[16]$} & $\begin{array}{l}\text { Asthma [16], gastric } \\
\text { problems, toothache [17] }\end{array}$ \\
\hline $\begin{array}{l}\text { Amaranthus cruentus L. } \\
\text { GA20171030NP002 }\end{array}$ & Latte $(\mathrm{N})$ & C & $\mathrm{L} / \mathrm{Sd}$ & food & $\begin{array}{l}\text { The leaves are cooked like spinach, added to soups, } \\
\text { or eaten raw. The seeds are cooked and used for } \\
\text { soups (satoo), or ground to obtain a flour for bread } \\
\text { (chapati). }\end{array}$ & & \\
\hline $\begin{array}{l}\text { Amaranthus hybridus L. } \\
\text { GA20171030NP003 }\end{array}$ & Latte $(\mathrm{N})$ & C & $\mathrm{L} / \mathrm{Sd}$ & food & $\begin{array}{l}\text { The leaves are cooked like spinach, added to soups, } \\
\text { or eaten raw. The seeds are cooked and used for } \\
\text { soups (satoo), or ground to obtain a flour for bread } \\
\text { (chapati). }\end{array}$ & & \\
\hline
\end{tabular}


Table 2. Cont

\begin{tabular}{|c|c|c|c|c|c|c|c|}
\hline $\begin{array}{l}\text { Family Scientific Name } \\
\text { Voucher Number }\end{array}$ & Vernacular Name $^{a}$ & Origin $^{b}$ & Parts Used $^{c}$ & Ethnobotanical Uses ${ }^{d}$ & Uses Description & $\begin{array}{l}\text { Similar Uses } \\
\text { References }\end{array}$ & Other Uses References \\
\hline $\begin{array}{l}\text { Amaranthus viridis L. } \\
\text { GA20181016NP098 }\end{array}$ & Gaute bangan $(\mathrm{T})$ & $\mathrm{W}$ & $\mathrm{R}$ & $\mathrm{med} / \mathrm{fev}$ & Root juice is used to cure high fever. & & \\
\hline \multicolumn{8}{|l|}{ Anacardiaceae } \\
\hline $\begin{array}{l}\text { Choerospondias axillaris } \\
\text { (Roxb.) B. L. Burtt \& A. W. } \\
\text { Hill } \\
\text { GA20171113NP048 }\end{array}$ & Lapsi $(\mathrm{N})$ & C & $\mathrm{Fr}$ & food & Fruits are eaten fresh or pickled. & & \\
\hline $\begin{array}{l}\text { Mangifera indica L. } \\
\text { GA20181017NP104 }\end{array}$ & Aanp (N) & C & $\mathrm{Fr}$ & $\mathrm{med} / \mathrm{gast}$ & The peel of fruits is boiled and eaten to cure gastritis. & {$[16,23,25]$} & $\begin{array}{l}\text { Jaundice,rheumatism } \\
\text { [16],dysentery [23] }\end{array}$ \\
\hline $\begin{array}{l}\text { Searsia parviflora (Roxb.) F. } \\
\text { A. Barkley (= Rhus parviflora } \\
\text { Roxb.) } \\
\text { GA20181016NP093 }\end{array}$ & Satibro $(\mathrm{T})$ & $\mathrm{W}$ & $\mathrm{Fr}$ & med/gast & $\begin{array}{l}\text { Ripe fruits are eaten to treat stomach problems and } \\
\text { diarrhea. }\end{array}$ & & \\
\hline \multicolumn{8}{|l|}{ Apiaceae } \\
\hline $\begin{array}{l}\text { Centella asiatica (L.) Urb. } \\
\text { GA20181018NP111 }\end{array}$ & $\begin{array}{l}\text { Tajoimra (T), } \\
\text { Kholachagaian, } \\
\text { Kolacha (Ne) }\end{array}$ & $\mathrm{W}$ & $\begin{array}{l}\text { Wp } \\
\mathrm{R}\end{array}$ & $\begin{array}{l}\text { med/fev,ant,musc,nerv } \\
\text { med/urogen }\end{array}$ & $\begin{array}{l}\text { Plant juice is drunk to cure fever and sometimes is } \\
\text { mixed with the juice of Drymaria cordata to treat high } \\
\text { fever. } \\
\text { A typical recipe (*) is used to cure fever, internal } \\
\text { fever, food poisoning, joint pain, migraine. } \\
\text { Root juice is drunk to cure urinary problems. }\end{array}$ & {$[19,23,26,27]$} & $\begin{array}{l}\text { Blood purification [19], } \\
\text { indigestion [20], skin } \\
\text { diseases [24], sinusitis [25] }\end{array}$ \\
\hline \multicolumn{8}{|l|}{ Apocynaceae } \\
\hline $\begin{array}{l}\text { Calotropis gigantea (L.) } \\
\text { Dryand. } \\
\text { GA20171030NP004 }\end{array}$ & $\begin{array}{l}\text { Arka (sanskrit), } \\
\text { Aank, Akh (T) }\end{array}$ & $\mathrm{W}$ & Lx & med/derm,musc & $\begin{array}{l}\text { Latex is used directly on the skin to stop bleeding } \\
\text { wounds and to treat ankle sprains. }\end{array}$ & & Joint fracture [23] \\
\hline $\begin{array}{l}\text { Catharanthus roseus (L.) G. } \\
\text { Don } \\
\text { GA20171101NP017 }\end{array}$ & Barhamase phul (N) & $\mathrm{N}$ & Wp & dom & The plant is used as an ornamental in home gardens. & & \\
\hline $\begin{array}{l}\text { Wrightia arborea (Dennst.) } \\
\text { Mabb. } \\
\text { GA20181017NP108 }\end{array}$ & Glemindhu (T) & W & $\mathrm{Fr} / \mathrm{Sd}$ & med/gast,fev & $\begin{array}{l}\text { The soft septum between one seed and the other, is } \\
\text { eaten to cure flatulence, intestinal pain with dark } \\
\text { stools, insolation with fever. }\end{array}$ & & \\
\hline \multicolumn{8}{|l|}{ Araceae } \\
\hline $\begin{array}{l}\text { Acorus calamus } \mathrm{L} \text {. } \\
\text { GA20181016NP096 }\end{array}$ & Seda $(\mathrm{T})$ & C & Wp & med/derm & $\begin{array}{c}\text { The plant is grated on a stone and applied on skin } \\
\text { wounds. }\end{array}$ & & $\begin{array}{l}\text { Cough/cold [19], } \\
\text { roundworm, hookworm } \\
\text { [23], fever [26] }\end{array}$ \\
\hline $\begin{array}{l}\text { Colocasia esculenta }(\text { L.) Schott } \\
\text { GA20181015NP087 }\end{array}$ & Pidalu (N), Taia (T) & C & $\mathrm{Rh}$ & $\begin{array}{l}\text { med/gast } \\
\text { food }\end{array}$ & $\begin{array}{l}\text { Some pieces of boiled rhizome are eaten to cure the } \\
\text { constipation of children (1-5 years). } \\
\text { Boiled rhizome is commonly eaten as food by the } \\
\text { people, especially for breakfast. }\end{array}$ & & \\
\hline
\end{tabular}


Table 2. Cont.

\begin{tabular}{|c|c|c|c|c|c|c|c|}
\hline $\begin{array}{c}\text { Family Scientific Name } \\
\text { Voucher Number }\end{array}$ & Vernacular Name $^{a}$ & Origin $^{b}$ & Parts Used ${ }^{c}$ & Ethnobotanical Uses ${ }^{d}$ & Uses Description & $\begin{array}{l}\text { Similar Uses } \\
\text { References }\end{array}$ & Other Uses References \\
\hline $\begin{array}{c}\text { Rhaphidophora glauca (Wall.) } \\
\text { Schott } \\
\text { GA20171111NP045 }\end{array}$ & Birlahra (T) & W & $\mathrm{Wp}$ & $\mathrm{med} / \mathrm{mat}$ & $\begin{array}{l}\text { To promote pregnancy, the juice of the plant is taken } \\
3 \text { times a week: Saturday,Tuesday,Thursday. }\end{array}$ & & \\
\hline \multicolumn{8}{|l|}{ Asparagaceae } \\
\hline $\begin{array}{l}\text { Agave cantala (Haw.) Roxb. } \\
\text { ex Salm-Dyck } \\
\text { GA20171030NP001 }\end{array}$ & Ketuki (N) & $\mathrm{N}$ & $\mathrm{L}$ & handicr & $\begin{array}{l}\text { Dried leaves are used for roofing. Leaves provide } \\
\text { fibers used to make ropes, cordage, and twine. }\end{array}$ & & $\begin{array}{l}\text { Diuretic, anti-syphilitic [20], } \\
\text { worms on wound [27] }\end{array}$ \\
\hline $\begin{array}{l}\text { Asparagus racemosus Willd. } \\
\text { GA20181015NP084 }\end{array}$ & Kurilo (N) & C & $\mathrm{R}$ & $\begin{array}{l}\text { med/met } \\
\text { vet }\end{array}$ & $\begin{array}{l}\text { Root juice is drunk to cure jaundice. } \\
\text { Root juice is mixed with corn flour and given to the } \\
\text { buffaloes for about } 2-3 \text { days, twice a day, to } \\
\text { stimulate milk production. }\end{array}$ & {$[19,23]$} & $\begin{array}{l}\text { Urinary disorders, } \\
\text { stimulation of milk } \\
\text { production in women [19] }\end{array}$ \\
\hline \multicolumn{8}{|l|}{ Asteraceae } \\
\hline $\begin{array}{l}\text { Ageratina adenophora } \\
\text { (Spreng.) R. M. King \& H. } \\
\text { Rob. GA20171109NP023 }\end{array}$ & Banmara $(\mathrm{N})$ & W & $\mathrm{L}$ & med/derm & $\begin{array}{l}\text { Five to seven leaves are crushed with water and the } \\
\text { green liquid extracted from the obtained paste is } \\
\text { applied on cuts and wounds to stop the bleeding. }\end{array}$ & {$[16,17,19,25-27]$} & Fever, eyes insomnia [16] \\
\hline $\begin{array}{l}\text { Artemisia indica Willd. } \\
\text { GA20171109NP025 }\end{array}$ & $\begin{array}{l}\text { Titepati (N), Dusun } \\
(\mathrm{Ne})\end{array}$ & W & $\begin{array}{l}\text { Wp } \\
\text { Ys }\end{array}$ & $\begin{array}{l}\text { rel } \\
\text { med/ant,resp,fev,musc,nerv } \\
\text { med/resp }\end{array}$ & $\begin{array}{c}\text { The dried plant is used as incense. } \\
\text { Plant juice is drunk to treat food poisoning and } \\
\text { cough. } \\
\text { A typical recipe }\left(^{*}\right) \text { is used to cure fever, internal } \\
\text { fever, food poisoning, joint pain, migraine. } \\
4-5 \text { shoots are crushed with water, the juice is } \\
\text { filtered and drunk for the treatment of throat } \\
\text { irritations. }\end{array}$ & [17] & $\begin{array}{l}\text { Gastritis, paralysis, [23], } \\
\text { rheumatic pain [24], cuts, } \\
\text { scabies [25], louse, worms } \\
\text { [27] }\end{array}$ \\
\hline $\begin{array}{l}\text { Bidens pilosa } \mathrm{L} \text {. } \\
\text { GA20181018NP110 }\end{array}$ & Buk tinai $(\mathrm{T})$ & $\mathrm{N}$ & $\mathrm{Fl}$ & med/fev,nerv & $\begin{array}{l}\text { The juice of flowers is drunk, twice a day (morning } \\
\text { and evening), to cure fever and migraine. }\end{array}$ & & Cuts and wounds [16] \\
\hline $\begin{array}{l}\text { Blainvillea acmella }(\mathrm{L} .) \\
\text { Philipson (= Spilanthes } \\
\text { acmella } \text { (L.) L.) } \\
\text { GA20181012NP054 }\end{array}$ & Saprumo $(\mathrm{T})$ & $\mathrm{N}$ & $\mathrm{R}$ & med/resp & $\begin{array}{l}\text { Root juice is drunk twice a day (morning and } \\
\text { evening) to cure cough and cold. }\end{array}$ & & \\
\hline $\begin{array}{l}\text { Blumea aromatica DC. } \\
\text { GA20181015NP085 }\end{array}$ & - & $\mathrm{N}$ & $\mathrm{Fl}$ & food & $\begin{array}{l}\text { The dried flowers are mixed with Clematis } \\
\text { buchananiana and Oryza sativa, and fermented for a } \\
\text { week to obtain a popular alcoholic drink (chhaang). }\end{array}$ & & \\
\hline $\begin{array}{l}\text { Cirsium wallichii DC. } \\
\text { GA20181012NP061 }\end{array}$ & $\begin{array}{l}\text { Thakal }(\mathrm{N}) \\
\text { Achangpolo }(\mathrm{T}) \\
\text { Chwacan }(\mathrm{Ne})\end{array}$ & W & $\mathrm{R}$ & med/urogen,genh,fev & $\begin{array}{l}\text { Root juice is drunk to treat urinary problems (blood } \\
\text { in the urine), weakness (the juice is taken twice a } \\
\text { day), malarial fever. }\end{array}$ & & \\
\hline
\end{tabular}


Table 2. Cont.

\begin{tabular}{|c|c|c|c|c|c|c|c|}
\hline $\begin{array}{l}\text { Family Scientific Name } \\
\text { Voucher Number }\end{array}$ & Vernacular Name $^{a}$ & Origin $^{b}$ & Parts Used ${ }^{c}$ & Ethnobotanical Uses ${ }^{d}$ & Uses Description & $\begin{array}{c}\text { Similar Uses } \\
\text { References }\end{array}$ & Other Uses References \\
\hline $\begin{array}{l}\text { Duhaldea cappa (Buch.-Ham. } \\
\text { ex D. Don) Pruski \& Anderb. } \\
\text { (= Inula cappa (Buch. Ham. } \\
\text { ex D. Don) DC.) } \\
\text { GA20181013NP069 }\end{array}$ & $\begin{array}{c}\text { Ranaven, } \\
\text { Ranabhyang (T) }\end{array}$ & $\mathrm{W}$ & $\mathrm{R}$ & $\mathrm{med} / \mathrm{fev}$ & Root juice is drunk to cure fever. & & $\begin{array}{l}\text { Snake bite, menstrual } \\
\text { disorders, epilepsy [19] } \\
\text { headache [23], gastritis, } \\
\text { indigestion [24] }\end{array}$ \\
\hline $\begin{array}{l}\text { Eclipta prostrata }(\mathrm{L} .) \text { L. } \\
\text { GA20181013NP066 }\end{array}$ & Mashi mra (T) & $\mathrm{W}$ & $\mathrm{St} / \mathrm{L}$ & med/derm & $\begin{array}{l}\text { The hand-crushed plant is applied directly to the } \\
\text { wounds of the skin. }\end{array}$ & & \\
\hline $\begin{array}{l}\text { Elephantopus scaber L. } \\
\text { GA20181013NP067 }\end{array}$ & $\begin{array}{l}\text { Buti jhar (N), Tinai } \\
\text { (T) }\end{array}$ & W & $\begin{array}{c}\mathrm{R} \\
\mathrm{Wp}\end{array}$ & $\begin{array}{l}\mathrm{med} / \mathrm{ant} \\
\mathrm{med} / \mathrm{met}\end{array}$ & $\begin{array}{l}\text { Root juice is drunk once/twice times in the } \\
\text { nighttime, in case of food poisoning. } \\
\text { Plant juice is taken to cure jaundice. In case of infant } \\
\text { jaundice, the mother drinks the juice before } \\
\text { breastfeeding the sick child. }\end{array}$ & & Headache, sinusitis [23] \\
\hline $\begin{array}{l}\text { Galinsoga parviflora Cav. } \\
\text { GA20171113NP049 }\end{array}$ & Bhuitimur (N) & $\mathrm{N}$ & $\mathrm{Fl}$ & med/ENT & $\begin{array}{l}3 \text { flowers are put on the sore tooth for } 15-30 \mathrm{~min} \text {. } \\
\text { Once is often enough to relieve toothache, but the } \\
\text { treatment can be repeated a second time after } 3 \text { days. }\end{array}$ & & \\
\hline $\begin{array}{l}\text { Smallanthus sonchifolius } \\
\text { (Poepp.) H. Rob. } \\
\text { GA20171113NP051 }\end{array}$ & Bhuishyau (N) & C & $\mathrm{R}$ & $\begin{array}{c}\mathrm{med} / \mathrm{met} \\
\text { food }\end{array}$ & $\begin{array}{l}\text { The tuberous root, cleaned and eaten raw, once per } \\
\text { week, is useful in case of diabetes. } \\
\text { Tubers are slightly sweet, crispy and juicy and are } \\
\text { usually eaten raw like a fruit. }\end{array}$ & & \\
\hline $\begin{array}{c}\text { Tagetes erecta } \text { L. }(=\text { Tagetes } \\
\text { patula } \text { L.) } \\
\text { GA20171030NP005 }\end{array}$ & $\begin{array}{c}\text { Sayapatri (N), } \\
\text { Saipatri sun (Ne) }\end{array}$ & C & $\mathrm{Fl}$ & $\begin{array}{c}\text { rel } \\
\text { med/derm,fev,ant,musc,nerv }\end{array}$ & $\begin{array}{l}\text { Flowers are used for the creation of garlands and } \\
\text { decorations for weddings, festivals, and other } \\
\text { religious events. } \\
\text { Flowers are rubbed on the injured and swollen skin. } \\
\text { A typical recipe (*) is used to cure fever, internal } \\
\text { fever, food poisoning, joint pain, migraine. }\end{array}$ & & \\
\hline \multicolumn{8}{|l|}{ Berberidaceae } \\
\hline $\begin{array}{l}\text { Berberis asiatica Roxb. ex DC. } \\
\text { GA20181012NP059 }\end{array}$ & Chutro (N) & $\mathrm{W}$ & $\mathrm{R}$ & med/fev,ENT,gast & $\begin{array}{l}\text { The root is boiled for } 5 \text { minutes in about } 1 / 2 \mathrm{~L} \text { of } \\
\text { water and the infusion is drunk to treat fever, } \\
\text { toothache, "red eyes" (conjunctivitis), mouth } \\
\text { infections, diarrhea. }\end{array}$ & {$[19,20,25]$} & Blood purification [19] \\
\hline \multicolumn{8}{|l|}{ Bignoniaceae } \\
\hline $\begin{array}{l}\text { Oroxylum indicum }(\mathrm{L} .) \text { Kurz } \\
\text { GA20181018NP113 }\end{array}$ & $\begin{array}{c}\text { Tatelo (N), Tarlason } \\
(\mathrm{Ne})\end{array}$ & $\mathrm{W}$ & $\mathrm{Sd}$ & $\begin{array}{c}\text { rel } \\
\text { med/derm } \\
\text { fev,ant,musc,nerv }\end{array}$ & $\begin{array}{l}\text { Seeds are widely used in religious ceremonies and } \\
\text { divinatory practices of shamans. } \\
\text { Seed are applied externally to heal cuts and wounds. } \\
\text { A typical recipe }\left(^{*}\right) \text { is used to cure fever, internal } \\
\text { fever, food poisoning, joint pain, migraine. }\end{array}$ & {$[17,26,27]$} & $\begin{array}{l}\text { Dysentery [26], jaundice } \\
{[27]}\end{array}$ \\
\hline
\end{tabular}


Table 2. Cont

\begin{tabular}{|c|c|c|c|c|c|c|c|}
\hline $\begin{array}{l}\text { Family Scientific Name } \\
\text { Voucher Number }\end{array}$ & Vernacular Name $^{a}$ & Origin $^{b}$ & Parts Used ${ }^{c}$ & Ethnobotanical Uses ${ }^{d}$ & Uses Description & $\begin{array}{l}\text { Similar Uses } \\
\text { References }\end{array}$ & Other Uses References \\
\hline \multicolumn{8}{|l|}{ Brassicaceae } \\
\hline $\begin{array}{l}\text { Brassica rapa L. (= Brassica } \\
\text { campestris var. sarson Prain) } \\
\text { GA20171031NP006 }\end{array}$ & Sarson $(\mathrm{N})$ & C & $\mathrm{Sd}$ & $\begin{array}{l}\text { food } \\
\mathrm{med} / \mathrm{ENT} \\
\mathrm{med} / \mathrm{musc}\end{array}$ & $\begin{array}{l}\text { The oil obtained by seeds is used to cook. } \\
\text { The ointment obtained mixing hot rapeseed oil and } \\
\text { dried bark of Myrica esculenta, is applied externally } \\
\text { to treat earache. } \\
\text { The ointment obtained mixing hot rapeseed oil with } \\
\text { leaves of } \text { Abrus precatorius, is used for massages in } \\
\text { case of joint pain, twice a day. }\end{array}$ & [16] & \\
\hline \multicolumn{8}{|l|}{ Capparaceae } \\
\hline $\begin{array}{l}\text { Crateva religiosa G. Forst. } \\
\text { GA20181015NP088 }\end{array}$ & Siplekan (N) & W & $\mathrm{Fr}$ & med/derm,ENT & $\begin{array}{l}\text { Dried fruits are grated on a stone with the addition } \\
\text { of water and the mixture is applied to the wounds of } \\
\text { the skin. } \\
\text { The fresh fruit liquid is applied externally to treat } \\
\text { the swelling of the dental glands and the affected } \\
\text { part is bandaged with "Nepali paper". } \\
\text { The young leaves are boiled and eaten to treat } \\
\text { stomach pain. }\end{array}$ & & \\
\hline \multicolumn{8}{|l|}{ Caprifoliaceae } \\
\hline $\begin{array}{l}\text { Valeriana hardwickii Wall. } \\
\text { GA20171112NP046 }\end{array}$ & Daling (T) & $\mathrm{W}$ & $\mathrm{R}$ & med/gast & $\begin{array}{l}\text { Fresh root juice or infusion of the dried root, is taken } \\
\text { twice a day for a week, to cure gastric problems and } \\
\text { vomiting. }\end{array}$ & & \\
\hline $\begin{array}{l}\text { Valeriana jatamansi Jones ex } \\
\text { Roxb } \\
\text { GA20181015NP082 }\end{array}$ & $\begin{array}{l}\text { Jatamasi (N), Dhalin } \\
\text { (T) }\end{array}$ & $\mathrm{W}$ & $\mathrm{R}$ & $\begin{array}{c}\text { med/gast,nerv } \\
\text { rel }\end{array}$ & $\begin{array}{l}\text { Root juice is taken to treat diarrhea in children. } \\
\text { With the dried roots shamans produce the incense } \\
\text { for the treatment of anxiety and insomnia. } \\
\text { Incense from the plant root is used for religious } \\
\text { purposes. }\end{array}$ & & Fire burns [26] \\
\hline \multicolumn{8}{|l|}{ Caricaceae } \\
\hline $\begin{array}{l}\text { Carica papaya L. } \\
\text { GA20171031NP007 }\end{array}$ & Papaya (I) & $\mathrm{C}$ & $\mathrm{Fr}$ & food & $\begin{array}{l}\text { Plant is cultivated in kitchen gardens for its edible } \\
\text { fruits. }\end{array}$ & & \\
\hline \multicolumn{8}{|l|}{ Caryophillaceae } \\
\hline $\begin{array}{l}\text { Arenaria benthamii Fenzl ex } \\
\text { Torr. and A. Gray } \\
\text { GA20181012NP057 }\end{array}$ & Tangne (T) & W & Wp & med/resp & $\begin{array}{l}\text { The pillows are filled with the plant so that the } \\
\text { active ingredients are inhaled during the night to } \\
\text { cure fever and breathing problems. }\end{array}$ & & \\
\hline
\end{tabular}


Table 2. Cont.

\begin{tabular}{|c|c|c|c|c|c|c|c|}
\hline $\begin{array}{c}\text { Family Scientific Name } \\
\text { Voucher Number }\end{array}$ & Vernacular Name ${ }^{a}$ & Origin $^{b}$ & Parts Used ${ }^{c}$ & Ethnobotanical Uses ${ }^{d}$ & Uses Description & $\begin{array}{c}\text { Similar Uses } \\
\text { References }\end{array}$ & Other Uses References \\
\hline $\begin{array}{l}\text { Drymaria cordata (L.) Willd. } \\
\text { ex Schult. } \\
\text { GA20171111NP042 }\end{array}$ & $\begin{array}{l}\text { Abijalo (N),Tangar, } \\
\text { Abijal (T), Abisal } \\
\text { ghe, Kai bugain (Ne) }\end{array}$ & $\mathrm{W}$ & $\mathrm{Wp}$ & med/fev,gast,ant,resp, musc,nerv & $\begin{array}{l}\text { The plant parts are pounded, boiled in water for } \\
\text { about } 5 \text { min and the filtrate is drunk once a day } \\
\text { (morning or evening) for } 3 \text { days, to cure fever. } \\
\text { Plant juice is drunk twice a day to cure fever and } \\
\text { stomach infections. } \\
\text { Plant juice is drunk to treat food poisoning, rhinitis, } \\
\text { and sinusitis. Sometimes the plant juice is mixed } \\
\text { with that of Centella asiatica to cure high fever. } \\
\text { A typical recipe } \text { ( }^{*} \text { is used to cure fever, internal } \\
\text { fever, food poisoning, joint pain, migraine. }\end{array}$ & {$[24,25]$} & \\
\hline \multicolumn{8}{|l|}{ Combretaceae } \\
\hline $\begin{array}{l}\text { Terminalia bellirica (Gaertn.) } \\
\text { Roxb. } \\
\text { GA20181017NP107 } \\
\end{array}$ & Barla (T) & $\mathrm{W}$ & Fr & med/resp,gast & $\begin{array}{l}\text { Fruits are kept in the mouth and sucked like candy } \\
\text { to cure cough and gastric problems. }\end{array}$ & {$[20,23,26,27]$} & Cold, cough [27] \\
\hline \multicolumn{8}{|l|}{ Convolvulaceae } \\
\hline $\begin{array}{l}\text { Cuscuta reflexa Roxb. } \\
\text { GA20181013NP065 }\end{array}$ & $\begin{array}{l}\text { Sikari lahara (N) } \\
\text { Sky grass (english) }\end{array}$ & $\mathrm{W}$ & St & med/met & $\begin{array}{l}\text { Used in case of jaundice: (a) the plant juice is drunk; } \\
\text { (b) the plant is pounded, boiled in water for } 2-3 \text { min } \\
\text { and the filtrate is drunk. }\end{array}$ & {$[19,20,23-27]$} & $\begin{array}{l}\text { Bone fractures, body } \\
\text { swelling [19], roundworm, } \\
\text { depression [23] }\end{array}$ \\
\hline \multicolumn{8}{|l|}{ Coriaraceae } \\
\hline $\begin{array}{l}\text { Coriaria nepalensis Wall. } \\
\text { GA20181017NP101 }\end{array}$ & $\begin{array}{l}\text { Bhujinshin (N) } \\
\text { Hakupaku (T) }\end{array}$ & $\mathrm{W}$ & $\begin{array}{c}\mathrm{Fr} \\
\mathrm{L} / \mathrm{St}\end{array}$ & med/gast & $\begin{array}{l}\text { Ripe fruits and plant juice are taken to treat } \\
\text { indigestion. }\end{array}$ & & \\
\hline \multicolumn{8}{|l|}{ Crassulaceae } \\
\hline $\begin{array}{l}\text { Bryophyllum pinnatum } \\
\text { (Lam.) Oken } \\
\text { GA20181012NP060 } \\
\end{array}$ & $\begin{array}{l}\text { Kidney stone } \\
\text { medicine }\end{array}$ & $\mathrm{N}$ & $\mathrm{L}$ & med/urogen & $\begin{array}{l}\text { Leaf juice is drunk, or the leaves are eaten raw to } \\
\text { cure urinary problems. }\end{array}$ & & \\
\hline \multicolumn{8}{|l|}{ Cucurbitaceae } \\
\hline $\begin{array}{l}\text { Momordica charantia L. } \\
\text { GA20181016NP090 }\end{array}$ & Karela (N) & C & $\mathrm{Fr}$ & $\begin{array}{c}\text { med/card } \\
\text { food }\end{array}$ & $\begin{array}{l}\text { Fruits are consumed to control high blood pressure. } \\
\text { Unripe fruits are cooked as a vegetable or pickled. }\end{array}$ & & \\
\hline \multicolumn{8}{|l|}{ Dioscoreaceae } \\
\hline $\begin{array}{l}\text { Dioscorea bulbifera } \mathrm{L} \text {. } \\
\text { GA20171110NP032 }\end{array}$ & $\begin{array}{l}\text { Dhingyui mindhu } \\
\text { (T) }\end{array}$ & $\mathrm{W}$ & $\mathrm{R}$ & $\mathrm{med} / \mathrm{mat}$ & $\begin{array}{l}\text { The root (white color) is cut into small pieces and } \\
\text { crushed to obtain a red juice, taken once a day } \\
\text { regularly, by women with menstrual cycle disorders, } \\
\text { for preventive purposes. }\end{array}$ & & $\begin{array}{r}\text { Piles, dysentery, syphilis, } \\
\text { ulcers [16], pneumonia [19] }\end{array}$ \\
\hline
\end{tabular}


Table 2. Cont

\begin{tabular}{|c|c|c|c|c|c|c|c|}
\hline $\begin{array}{l}\text { Family Scientific Name } \\
\text { Voucher Number }\end{array}$ & Vernacular Name ${ }^{a}$ & Origin $^{b}$ & Parts Used ${ }^{c}$ & Ethnobotanical Uses ${ }^{d}$ & Uses Description & $\begin{array}{c}\text { Similar Uses } \\
\text { References }\end{array}$ & Other Uses References \\
\hline \multicolumn{8}{|l|}{ Euphorbiaceae } \\
\hline $\begin{array}{l}\text { Euphorbia hirta L. } \\
\text { GA20181017NP103 }\end{array}$ & $\begin{array}{l}\text { Rato lahare }(\mathrm{N}) \\
\text { Walagughi }(\mathrm{T})\end{array}$ & $\mathrm{W}$ & Lx & med/derm,musc & $\begin{array}{l}\text { Latex is applied on skin wounds and joint trauma } \\
\text { without bone fractures. }\end{array}$ & {$[16,26]$} & $\begin{array}{l}\text { Diarrhoea/dysentery, } \\
\text { respiratory diseases, snake } \\
\text { bites [16], excessive } \\
\text { menstrual flow [24] }\end{array}$ \\
\hline $\begin{array}{l}\text { Jatropha curcas L. } \\
\text { GA20171031NP010 }\end{array}$ & $\begin{array}{l}\text { Arin,Sajiwan (N) } \\
\text { Mandhar (T) }\end{array}$ & $\mathrm{N}$ & $\begin{array}{c}\mathrm{St} \\
\mathrm{Fr} / \mathrm{Lx}\end{array}$ & $\begin{array}{l}\mathrm{med} / \mathrm{ENT} \\
\mathrm{med} / \mathrm{derm}\end{array}$ & $\begin{array}{l}\text { The most tender twigs are used for cleaning the } \\
\text { teeth. } \\
\text { Dried fruits or latex are applied externally in case of } \\
\text { skin infections. }\end{array}$ & {$[23,24,26]$} & Gum problems [24] \\
\hline $\begin{array}{l}\text { Ricinus communis L. } \\
\text { GA20181018NP116 }\end{array}$ & Taturoro (Ne) & $\mathrm{N}$ & $\mathrm{Fl}$ & vet & $\begin{array}{l}\text { The flowers are pounded with water and the paste } \\
\text { obtained is applied to treat skin problems of cattle. }\end{array}$ & & $\begin{array}{l}\text { Bone fractures [23], worms } \\
\text { in the teeth [24] }\end{array}$ \\
\hline \multicolumn{8}{|l|}{ Fabaceae } \\
\hline $\begin{array}{l}\text { Abrus precatorius L. } \\
\text { GA20181012NP055 }\end{array}$ & Rati geri $(\mathrm{N})$ & $\mathrm{W}$ & $\begin{array}{l}\mathrm{R} \\
\mathrm{L}\end{array}$ & $\begin{array}{l}\text { med/nerv,resp, ant } \\
\text { med/musc }\end{array}$ & $\begin{array}{l}\text { The root is grated on a stone and inhaled to treat } \\
\text { migraine. The root is grated on a stone, mixed with } \\
\text { honey, and taken to cure cough. The dried root is } \\
\text { pulverized and applied on snake bites, and the } \\
\text { affected part is banded with "Nepali paper". } \\
\text { The ointment obtained by cooking the leaves with } \\
\text { rapeseed oil is used to massage the aching joints, } \\
\text { twice a day. }\end{array}$ & & Stomach problems [27] \\
\hline $\begin{array}{l}\text { Albizia julibrissin Durazz. } \\
\text { GA20181016NP097 }\end{array}$ & Shirish $(\mathrm{N})$ & $\mathrm{W}$ & $\mathrm{R}$ & $\mathrm{med} / \mathrm{musc}$ & $\begin{array}{c}\text { The root is cut into small pieces and boiled for more } \\
\text { than } 3 \mathrm{~h} \text { along with Osyris wightiana and Senegalia } \\
\text { catechu; the filtered juice is applied externally in case } \\
\text { of bone fractures and the affected part is bandaged } \\
\text { with "Nepali paper". }\end{array}$ & & \\
\hline $\begin{array}{l}\text { Bauhinia variegata } \mathrm{L} \text {. } \\
\text { GA20181012NP058 }\end{array}$ & Koiralo (N) & $\mathrm{W}$ & $\mathrm{Br}$ & med/ENT,met,ant & $\begin{array}{l}\text { The bark is boiled in about half liter of water. So } \\
\text { water is used for gargling, in case of mouth } \\
\text { infections and toothache. Even the dried bark can be } \\
\text { used to trat toothache. } \\
\text { The dried bark is powdered, mixed with Zingiber } \\
\text { officinale powder and water. The dough obtained is } \\
\text { applied externally on the throat, twice a day } \\
\text { (morning and evening) in the treatment of goiter. } \\
\text { Dried and pulverized bark is mixed with the juice of } \\
\text { Citrus } \times \text { limon; the dough obtained is applied on } \\
\text { snake bites and the part is bandaged. }\end{array}$ & & $\begin{array}{l}\text { Diarrhoea/dysentery, piles } \\
\text { [20], gastritis [25], fever [27] }\end{array}$ \\
\hline
\end{tabular}


Table 2. Cont

\begin{tabular}{|c|c|c|c|c|c|c|c|}
\hline $\begin{array}{l}\text { Family Scientific Name } \\
\text { Voucher Number }\end{array}$ & Vernacular Name ${ }^{a}$ & Origin $^{b}$ & Parts Used ${ }^{c}$ & Ethnobotanical Uses ${ }^{d}$ & Uses Description & $\begin{array}{c}\text { Similar Uses } \\
\text { References }\end{array}$ & Other Uses References \\
\hline $\begin{array}{l}\text { Lablab purpureus (L.) Sweet } \\
\text { GA20171110NP033 }\end{array}$ & Lahare guki (T) & C & $\mathrm{L}$ & med/gast & $\begin{array}{l}\text { The leaves are boiled for about 5-10 minutes, } \\
\text { resulting in a daal-like soup, which is consumed } \\
\text { regularly to treat kabjiat (constipation). }\end{array}$ & & Ringworm on skin [27] \\
\hline $\begin{array}{l}\text { Phaseolus vulgaris L. } \\
\text { GA20171031NP014 }\end{array}$ & Rajama (N) & C & $\mathrm{Fr} / \mathrm{Sd}$ & food & $\begin{array}{l}\text { Fruits and seeds are used as vegetable and for } \\
\text { cooking daal (lentil soup). }\end{array}$ & & \\
\hline $\begin{array}{c}\text { Saraca asoca (Roxb.) J.J.de } \\
\text { Wilde } \\
\text { GA20181017NP106 }\end{array}$ & Ashoka $(\mathrm{N})$ & $\mathrm{W}$ & $\mathrm{Sd}$ & $\mathrm{med} / \mathrm{musc}$ & $\begin{array}{l}\text { The seeds are taken with water to bring relief in case } \\
\text { of bone fractures. }\end{array}$ & & \\
\hline $\begin{array}{l}\text { Senegalia catechu }(\text { L. f.) } \\
\text { P.J.H.Hurter and Mabb. } \\
\text { (=Acacia catechu }(\text { L. f.) } \\
\text { Willd.) } \\
\text { GA20181016NP095 }\end{array}$ & Khayar (T) & $\mathrm{W}$ & $\mathrm{R}$ & $\mathrm{med} / \mathrm{musc}$ & $\begin{array}{l}\text { The root is cut into small pieces and boiled: the } \\
\text { decoction is applied externally to promote the } \\
\text { healing of bone fractures. } \\
\text { Another recipe: small pieces of root are boiled for } \\
\text { more than } 3 \mathrm{~h} \text { along with Osyris wightiana and } \\
\text { Albizia julibrissin; the liquid obtained is applied on } \\
\text { the affected part and the part is banded with } \\
\text { "Nepali paper". }\end{array}$ & [26] & $\begin{array}{l}\text { Diarrhoea/dysentery [23], } \\
\text { fever [26] }\end{array}$ \\
\hline \multicolumn{8}{|l|}{ Gentianaceae } \\
\hline $\begin{array}{l}\text { Swertia angustifolia } \\
\text { Buch.-Ham. ex D. Don } \\
\text { GA20181014NP079 }\end{array}$ & $\begin{array}{l}\text { Chiraito (N), } \\
\text { Kampman (T) }\end{array}$ & $\mathrm{W}$ & $\begin{array}{l}\mathrm{R} / \mathrm{L} \\
\mathrm{Wp}\end{array}$ & $\mathrm{med} / \mathrm{fev}$ & $\begin{array}{l}\text { To treat fever: (a) root and leaf juice is drunk; (b) the } \\
\text { whole plant is put in water for } 12 \mathrm{~h} \text {, then the } \\
\text { macerate is drunk twice a day. }\end{array}$ & [16] & $\begin{array}{l}\text { Blood purification, bile } \\
\text { diseases, cough/cold [16] }\end{array}$ \\
\hline \multicolumn{8}{|l|}{ Iridaceae } \\
\hline $\begin{array}{c}\text { Iris domestica }(\mathrm{L} .) \text { Goldblatt } \\
\text { \& Mabb. } \\
\text { GA20171110NP029 }\end{array}$ & Darware mindhu $(\mathrm{T})$ & C & $\mathrm{R}$ & med/gast,ant & $\begin{array}{l}\text { The root juice is used in case of gastric problems and } \\
\text { poisoning, once a day, in the morning. }\end{array}$ & & Diarrhoea [27] \\
\hline \multicolumn{8}{|l|}{ Lamiaceae } \\
\hline $\begin{array}{l}\text { Colebrookea oppositiffolia Sm. } \\
\text { GA20171031NP008 }\end{array}$ & $\begin{array}{l}\text { Dhursil (N), Busul } \\
\text { sul (T) }\end{array}$ & $\mathrm{w}$ & $\begin{array}{l}\text { Fl } \\
\text { St } \\
\text { L }\end{array}$ & $\begin{array}{c}\text { rel } \\
\text { med/derm } \\
\text { med/gast }\end{array}$ & $\begin{array}{l}\text { Flowers are sold in urban markets for temple } \\
\text { offerings. } \\
\text { Thin stem filaments are applied to cuts and wounds } \\
\text { and the affected part is bandaged. } \\
\text { Hand-crushed leaf juice is drunk by children in case } \\
\text { of liquid diarrhea accompanied by abdominal pains. }\end{array}$ & {$[16,17]$} & $\begin{array}{l}\text { Epilepsy, fever, headache, } \\
\text { sinusitis [16], arthritis [17] }\end{array}$ \\
\hline $\begin{array}{l}\text { Leucas cephalotes (Roth) } \\
\text { Spreng. } \\
\text { GA20181013NP070 }\end{array}$ & Topdoi mra (T) & $\mathrm{W}$ & $\mathrm{Fl}$ & med/met,musc & $\begin{array}{l}\text { The infusion of flowers is drunk to cure jaundice } \\
\text { and joint pain. }\end{array}$ & & \\
\hline $\begin{array}{l}\text { Mentha spicata L. } \\
\text { GA20181018NP112 }\end{array}$ & Naasun $(\mathrm{Ne})$ & $\mathrm{W}$ & $\mathrm{Fl}$ & med/fev,ant,musc,nerv & $\begin{array}{l}\text { A typical recipe }\left(^{*}\right) \text { is used to cure fever, internal } \\
\text { fever, food poisoning, joint pain, migraine. }\end{array}$ & & $\begin{array}{c}\text { Gastric and intestinal } \\
\text { disorders [16], insomnia } \\
{[25]}\end{array}$ \\
\hline
\end{tabular}


Table 2. Cont

\begin{tabular}{|c|c|c|c|c|c|c|c|}
\hline $\begin{array}{l}\text { Family Scientific Name } \\
\text { Voucher Number }\end{array}$ & Vernacular Name ${ }^{a}$ & Origin $^{b}$ & Parts Used ${ }^{c}$ & Ethnobotanical Uses ${ }^{d}$ & Uses Description & $\begin{array}{c}\text { Similar Uses } \\
\text { References }\end{array}$ & Other Uses References \\
\hline $\begin{array}{l}\text { Ocimum tenuiflorum L. } \\
\text { GA20171031NP012 }\end{array}$ & Tulsi (N) & C & $\mathrm{Wp}$ & $\begin{array}{c}\text { rel } \\
\text { med/gast,ENT }\end{array}$ & $\begin{array}{l}\text { The plant is considered sacred and is used in the } \\
\text { worship of Vishnu. } \\
\text { The plant is used to prepare a herbal tea useful for } \\
\text { gastric problems and dry mouth. }\end{array}$ & & $\begin{array}{l}\text { Blood pressure control, ear } \\
\text { pain, respiratory diseases, } \\
\text { typhoid [23] }\end{array}$ \\
\hline $\begin{array}{l}\text { Perilla frutescens (L.) Britton } \\
\text { GA20171031NP013 }\end{array}$ & Silam $(\mathrm{N})$ & $\mathrm{W}$ & $\mathrm{Sd} / \mathrm{L}$ & food & $\begin{array}{l}\text { Toasted seeds are used to prepare a spicy sauce } \\
\text { (silam ko achar); the leaves cooked like spinach; dried } \\
\text { leaves are used to prepare an healthy herbal tea. }\end{array}$ & & \\
\hline $\begin{array}{l}\text { Pogostemon benghalensis } \\
\text { (Burm. f.) Kuntze } \\
\text { GA20171111NP044 }\end{array}$ & Rutula (T) & $\mathrm{W}$ & $\mathrm{Wp}$ & med/resp & $\begin{array}{l}\text { Plant juice is filtered and drunk, twice a day for a } \\
\text { week, to treat dry and tickly cough. }\end{array}$ & {$[23,27]$} & Typhoid [23] \\
\hline \multicolumn{8}{|l|}{ Lauraceae } \\
\hline $\begin{array}{l}\text { Cinnamomum glanduliferum } \\
\text { (Wall.) Meisn. } \\
\text { GA20181016NP099 }\end{array}$ & Tagba (T) & W & $\mathrm{R}$ & med/musc & $\begin{array}{l}\text { The root is crushed, boiled for more than an hour } \\
\text { and the mush obtained is used to massage the } \\
\text { painful joints, twice a day. }\end{array}$ & & Toothache, wounds [19] \\
\hline $\begin{array}{l}\text { Litsea cubeba (Lour.) Pers. } \\
\text { GA20181013NP071 }\end{array}$ & Siltimur $(\mathrm{N})$ & $\mathrm{W}$ & $\mathrm{Fr}$ & med/gast & $\begin{array}{l}\text { The dried ripe fruits, pulverized and dissolved in } \\
\text { water, are taken twice a day to treat stomach } \\
\text { problems. }\end{array}$ & & Cholera [20] \\
\hline $\begin{array}{l}\text { Machilus odoratissima Nees } \\
\text { (= Persea odoratissima } \text { (Nees) } \\
\text { Kosterm. } \\
\text { GA20181014NP076 }\end{array}$ & Kaulo (N) & $\mathrm{W}$ & $\mathrm{Br}$ & med/card,musc, urigen & $\begin{array}{l}\text { Dried bark is cut into small pieces, reduced to } \\
\text { powder, mixed with honey and taken } 7 \text { times a day. } \\
\text { Useful for heart attack, bone fractures, poor blood } \\
\text { circulation, urinary problems. }\end{array}$ & & \\
\hline \multicolumn{8}{|l|}{ Lythraceae } \\
\hline $\begin{array}{l}\text { Woodfordia fruticosa (L.) } \\
\text { Kurz } \\
\text { GA20171110NP038 }\end{array}$ & $\begin{array}{l}\text { Daduimre, Bhyur } \\
\text { ghara }(\mathrm{T})\end{array}$ & $\mathrm{W}$ & $\begin{array}{l}\mathrm{R} \\
\mathrm{Ys}\end{array}$ & med/gast & $\begin{array}{l}\text { Root juice is drunk for stomach problems. } \\
\text { The juice of about } 1 \mathrm{~kg} \text { of twig young shoots (red } \\
\text { color) is drunk once/twice times a day to treat } \\
\text { abdominal pain with blood in the stool. }\end{array}$ & {$[20,23,25-27]$} & \\
\hline \multicolumn{8}{|l|}{ Malvaceae } \\
\hline $\begin{array}{l}\text { Gossypium arboreum L. } \\
\text { GA20171031NP009 }\end{array}$ & Kopi (T) & C & $\mathrm{Sd}$ & handicr & $\begin{array}{l}\text { The fibres from the seeds are used in the production } \\
\text { of blankets and wicks for incense. }\end{array}$ & & \\
\hline \multicolumn{8}{|l|}{ Melastomataceae } \\
\hline $\begin{array}{l}\text { Osbeckia nepalensis Hook. } \\
\text { GA20181014NP075 }\end{array}$ & Chulsi (N) & $\mathrm{W}$ & $\mathrm{Wp}$ & med/derm & $\begin{array}{l}\text { The mixture obtained by crushing and mixing the } \\
\text { plant with Rubus ellipticus whole plant, is applied } \\
\text { directly on skin infections that tend to expand, } \\
\text { especially on the abdomen. }\end{array}$ & [24] & Fever [27] \\
\hline
\end{tabular}


Table 2. Cont

\begin{tabular}{|c|c|c|c|c|c|c|c|}
\hline $\begin{array}{c}\text { Family Scientific Name } \\
\text { Voucher Number }\end{array}$ & Vernacular Name ${ }^{a}$ & Origin $^{b}$ & Parts Used ${ }^{c}$ & Ethnobotanical Uses ${ }^{d}$ & Uses Description & $\begin{array}{c}\text { Similar Uses } \\
\text { References }\end{array}$ & Other Uses References \\
\hline \multicolumn{8}{|l|}{ Meliaceae } \\
\hline $\begin{array}{l}\text { Cipadessa baccifera (Roth) } \\
\text { Miq. } \\
\text { GA20181016NP100 }\end{array}$ & Painati (T) & $\mathrm{W}$ & $\mathrm{Br}$ & med/ant & $\begin{array}{l}\text { The juice from some stem slices is drunk to cause } \\
\text { vomiting against the food/drink poisoning. }\end{array}$ & & Cough/cold [16] \\
\hline $\begin{array}{l}\text { Melia azedarach L. } \\
\text { GA20181017NP105 }\end{array}$ & Bakaino, Bakena $(\mathrm{N})$ & $\mathrm{W}$ & $\mathrm{Br}$ & med/nerv,resp,fev,gast & $\begin{array}{l}\text { The bark powder, mixed with honey, is consumed to } \\
\text { treat migraine. } \\
\text { A rag, soaked in the boiling water of the bark, is put } \\
\text { on the forehead to treat cooling diseases. } \\
\text { The bark is cut into small pieces, reduced to powder, } \\
\text { mixed with Citrus } \times \text { limon juice and honey, and } \\
\text { eaten to cure fever. } \\
\text { The bark juice is drunk twice a day for } 3 \text { days in case } \\
\text { of gastric infections. }\end{array}$ & {$[16,20,26]$} & $\begin{array}{l}\text { Skin diseases, hysteria, } \\
\text { rheumatic pain [16], } \\
\text { diarrhoea, constpation, } \\
\text { cholera [23] }\end{array}$ \\
\hline $\begin{array}{l}\text { Toona hexandra (Wall.) M. } \\
\text { Roem. (= Toona ciliata M. } \\
\text { Roem.) } \\
\text { GA20171101NP022 }\end{array}$ & Tuni (T) & $\mathrm{W}$ & Wood & handicr & Wood is used for the production of furniture. & {$[16,17]$} & $\begin{array}{l}\text { Infantile dysentery, ulcer } \\
\text { and boils [16] }\end{array}$ \\
\hline \multicolumn{8}{|l|}{ Menispermaceae } \\
\hline $\begin{array}{l}\text { Stephania glandulifera Miers } \\
\text { GA20171110NP037 }\end{array}$ & Gundri gano $(\mathrm{T})$ & $\mathrm{W}$ & $\mathrm{R}$ & med/gast,mat,ant & $\begin{array}{l}\text { Root juice is drunk once a day (morning or evening) } \\
\text { to treat gastritis, menstrual disorders, and food } \\
\text { poisoning. }\end{array}$ & & Cough [27] \\
\hline $\begin{array}{l}\text { Tinospora sinensis (Lour.) } \\
\text { Merr. } \\
\text { GA20181015NP081 }\end{array}$ & Gurjo (N) & $\mathrm{W}$ & St & med/genh,card & $\begin{array}{l}\text { Stem juice or pieces of it are taken in case of cancer } \\
\text { and piles. }\end{array}$ & & $\begin{array}{l}\text { Menstruation problems [20] } \\
\text { diarrhoea, dysentery, } \\
\text { stomachache [23] }\end{array}$ \\
\hline \multicolumn{8}{|l|}{ Moraceae } \\
\hline $\begin{array}{l}\text { Ficus racemosa } \mathrm{L} \text {. } \\
\text { GA20181013NP068 }\end{array}$ & Dumri (N) & $\mathrm{W}$ & $\begin{array}{l}\mathrm{Fr} \\
\mathrm{Lx}\end{array}$ & $\begin{array}{l}\mathrm{med} / \mathrm{card} \\
\mathrm{med} / \mathrm{derm}\end{array}$ & $\begin{array}{l}\text { Ripe fruits are eaten to treat blood circulation } \\
\text { disorders. } \\
\text { Latex is applied to the skin affected by } \\
\text { dermatological diseases. }\end{array}$ & [27] & Diarrhoea [26] \\
\hline $\begin{array}{l}\text { Ficus semicordata } \\
\text { Buch.-Ham. ex Sm. } \\
\text { GA20171110NP034 }\end{array}$ & Ngedhore (T) & $\mathrm{W}$ & $\mathrm{Br}$ & med/gast & $\begin{array}{l}\text { The bark of stem portion near the ground is crushed } \\
\text { and boiled in a copper pot for about } 3 \mathrm{~h} \text {, adding } \\
\text { small pieces of copper. The filtrate is drunk adding } \\
\text { honey, twice a day, to treat dysentery with blood in } \\
\text { the stool. }\end{array}$ & & Scabies [25], wounds [26] \\
\hline
\end{tabular}


Table 2. Cont.

\begin{tabular}{|c|c|c|c|c|c|c|c|}
\hline $\begin{array}{l}\text { Family Scientific Name } \\
\text { Voucher Number }\end{array}$ & Vernacular Name $^{\text {a }}$ & Origin $^{b}$ & Parts Used $^{c}$ & Ethnobotanical Uses ${ }^{d}$ & Uses Description & $\begin{array}{l}\text { Similar Uses } \\
\text { References }\end{array}$ & Other Uses References \\
\hline \multicolumn{8}{|l|}{ Musaceae } \\
\hline $\begin{array}{l}\text { Musa } \times \text { paradisiaca } \mathrm{L} \\
\text { GA20171101NP020 }\end{array}$ & Kera $(\mathrm{N})$ & C & $\mathrm{Fr}$ & food & $\begin{array}{l}\text { Ripe fruits are edible and green bananas are cooked } \\
\text { like vegetables. }\end{array}$ & {$[16,26]$} & $\begin{array}{l}\text { Intestinal disorders, } \\
\text { diabetes, uremia, nephritis, } \\
\text { gout, hypertension, cardiac } \\
\text { diseases [16], jaundice [27] }\end{array}$ \\
\hline \multicolumn{8}{|l|}{ Myricaceae } \\
\hline $\begin{array}{l}\text { Myrica esculenta Buch.-Ham. } \\
\text { ex D. Don } \\
\text { GA20181014NP072 }\end{array}$ & Kaphal (N) & $\mathrm{W}$ & $\mathrm{Br}$ & med/nerv,ENT,derm,resp & $\begin{array}{l}\text { Dry bark powder is used in various remedies: it is } \\
\text { inhaled } 3 \text { times a day to treat headache; in case of } \\
\text { toothache, the teeth are washed with the mixture of } \\
\text { bark powder and Citrus } \times \text { limon; to treat earache, the } \\
\text { bark powder is mixed with hot rapeseed oil to make } \\
\text { an ointment for earache; to treat skin problems, the } \\
\text { bark powder is applied to the skin with a "Nepali } \\
\text { paper" bandage. } \\
\text { For the treatment of sore throat the fresh bark is cut } \\
\text { into small pieces which are placed inside the leaves } \\
\text { of Piper betle ("paan") and eaten like candy. }\end{array}$ & {$[19,27]$} & $\begin{array}{l}\text { Constipation [17], } \\
\text { diarrhoea, asthma [19], } \\
\text { bronchitis [24], cholera [26] }\end{array}$ \\
\hline \multicolumn{8}{|l|}{ Myrtaceae } \\
\hline $\begin{array}{l}\text { Psidium guajava } \mathrm{L} \text {. } \\
\text { GA20181016NP92 }\end{array}$ & Amba (T), Guava (I) & $\mathrm{N}$ & $\mathrm{Br}$ & med/gast & $\begin{array}{l}\text { The bark juice from the stem portion near the } \\
\text { ground is drunk to treat severe belly pains with } \\
\text { blood in the stool. }\end{array}$ & {$[16,20,23,26,27]$} & $\begin{array}{l}\text { Skin problems, rheumatism, } \\
\text { cholera, headache [16], } \\
\text { anthelmintic [23],blood } \\
\text { pressure control [25] }\end{array}$ \\
\hline $\begin{array}{l}\text { Syzygium cumini }(\text { L.) Skeels } \\
\text { GA20181015NP080 }\end{array}$ & Jamuna $(\mathrm{N})$ & W & $\mathrm{Fr}$ & med/met & $\begin{array}{l}\text { The dried ripe fruit powder is diluited with water } \\
\text { and drunk twice a day to control diabetes. }\end{array}$ & & Diarrhoea [23], typhoid [26] \\
\hline \multicolumn{8}{|l|}{ Oleaceae } \\
\hline $\begin{array}{l}\text { Jasminum mesnyi Hance } \\
\text { GA20171113NP050 }\end{array}$ & $\begin{array}{l}\text { Ghyi fui (N), Gaiful } \\
\text { (T) }\end{array}$ & $\mathrm{N}$ & $\mathrm{R} / \mathrm{Wp}$ & $\mathrm{med} / \mathrm{fev}$ & $\begin{array}{l}\text { Root juice is taken once a day for } 3 \text { days to cure } \\
\text { fever and the juice of the whole plant is used to cure } \\
\text { typhoid. }\end{array}$ & & \\
\hline $\begin{array}{l}\text { Nyctanthes arbor-tristis L. } \\
\text { GA20181014NP074 }\end{array}$ & Parijat (N) & W & $\mathrm{L}$ & $\mathrm{med} / \mathrm{fev}$ & Leaf juice is drunk to cure fever. & & Cold/cough $[26,27]$ \\
\hline \multicolumn{8}{|l|}{ Oxalidaceae } \\
\hline $\begin{array}{l}\text { Oxalis corniculata L. } \\
\text { GA20181018NP114 }\end{array}$ & $\begin{array}{c}\text { Pang qui, } \\
\text { Nakbruigumba (T), } \\
\text { Pauja gai (Ne) }\end{array}$ & W & Wp & med/musc,fev,ant,nerv & $\begin{array}{l}\text { Plant juice is drunk to treat joint pain and internal } \\
\text { fever. } \\
\text { A typical recipe }{ }^{*} \text { ) is used to cure fever, internal } \\
\text { fever, food poisoning, joint pain, migraine. }\end{array}$ & {$[23,26]$} & $\begin{array}{l}\text { Cataract [24], sinusitis [25], } \\
\text { conjunctivitis, typhoid [26] }\end{array}$ \\
\hline
\end{tabular}


Table 2. Cont

\begin{tabular}{|c|c|c|c|c|c|c|c|}
\hline $\begin{array}{c}\text { Family Scientific Name } \\
\text { Voucher Number }\end{array}$ & Vernacular Name ${ }^{a}$ & Origin $^{b}$ & Parts Used ${ }^{c}$ & Ethnobotanical Uses $^{d}$ & Uses Description & $\begin{array}{c}\text { Similar Uses } \\
\text { References }\end{array}$ & Other Uses References \\
\hline \multicolumn{8}{|l|}{ Phyllanthaceae } \\
\hline $\begin{array}{l}\text { Phyllanthus emblica L. } \\
\text { GA20171101NP021 }\end{array}$ & Amala $(\mathrm{N})$ & $\mathrm{W}$ & $\mathrm{Fr}$ & med/resp & $\begin{array}{l}\text { The fruits are consumed as expectorants in case of } \\
\text { cough and sore throat. }\end{array}$ & {$[23,26,27]$} & $\begin{array}{l}\text { Hearth pain, constipation, } \\
\text { diarrhoea [23], gastritis [26 }\end{array}$ \\
\hline \multicolumn{8}{|l|}{ Piperaceae } \\
\hline $\begin{array}{c}\text { Piper betle L. } \\
\text { GA20181014NP077 }\end{array}$ & $\operatorname{Paan}(\mathrm{N})$ & $\mathrm{W}$ & $\mathrm{L}$ & med/resp & $\begin{array}{l}\text { The leaves of Piper betle ("paan") are used, in case of } \\
\text { sore throat, to envelop small pieces of bark of Myrica } \\
\text { esculenta, and therefore taken like candy. }\end{array}$ & & \\
\hline $\begin{array}{l}\text { Piper retrofractum Vahl } \\
\text { GA20171110NP036 }\end{array}$ & Pan gughi (T) & $\mathrm{N}$ & St & med/gast & $\begin{array}{l}\text { The stem, fresh or dried, is used for the treatment of } \\
\text { gastric disorders. The stem is chewed or pounded to } \\
\text { obtain a juice to drink. }\end{array}$ & & \\
\hline \multicolumn{8}{|l|}{ Plumbaginaceae } \\
\hline $\begin{array}{l}\text { Plumbago zeylanica L. } \\
\text { GA20171111NP043 }\end{array}$ & $\begin{array}{l}\text { Chitu (N), Ping } \\
\quad \text { chittu (T) }\end{array}$ & $\mathrm{W}$ & $\underset{\mathrm{Wp}}{\mathrm{Wp}}$ & $\begin{array}{c}\text { med/gast } \\
\text { food }\end{array}$ & $\begin{array}{l}\text { Plant juice is drunk, twice a day for a week, to treat } \\
\text { gastric disorders. } \\
\text { Young leaves are cooked in rapeseed oil. }\end{array}$ & [23] & $\begin{array}{l}\text { Skin diseases [23], retentiol } \\
\text { of urine [26] }\end{array}$ \\
\hline \multicolumn{8}{|l|}{ Poaceae } \\
\hline $\begin{array}{l}\text { Eulaliopsis binata (Retz.) } \\
\text { C.E.Hubb. } \\
\text { GA20171101NP018 }\end{array}$ & Arkhen khar $(\mathrm{N})$ & $\mathrm{W}$ & $\mathrm{Wp}$ & dom & The dried plant is used as thatching roof. & [16] & \\
\hline $\begin{array}{l}\text { Oryza sativa L. } \\
\text { GA20181016NP091 }\end{array}$ & $\begin{array}{l}\text { Sun (T), } \\
\text { Nalasun (Ne) }\end{array}$ & C & $\begin{array}{l}\mathrm{Fr} \\
\text { Ys }\end{array}$ & $\begin{array}{c}\text { food } \\
\text { med/fev,ant,musc,nerv }\end{array}$ & $\begin{array}{l}\text { Rice is used in the preparation, along with Blumea } \\
\text { aromatica and Clematis buchananiana, of the } \\
\text { "chhaang" alcoholic beverage. } \\
\text { A typical Newar recipe (*) is used to cure fever, } \\
\text { internal fever, food poisoning, joint pain, migraine. }\end{array}$ & [16] & $\begin{array}{l}\text { Hearth inflammation, } \\
\text { indigestion [16] }\end{array}$ \\
\hline $\begin{array}{l}\text { Saccharum officinarum } \mathrm{L} \text {. } \\
\text { GA20171109NP026 }\end{array}$ & Ukhu (N) & C & St & $\begin{array}{c}\text { food } \\
\text { med/urigen }\end{array}$ & $\begin{array}{l}\text { Stem is sucked like candy or crushed to extract the } \\
\text { sweetened juice. } \\
\text { The stem, preferably the portion closest to the } \\
\text { ground, is chewed when the bladder feels swollen } \\
\text { and the urine is dark yellow. }\end{array}$ & {$[16]$} & $\begin{array}{l}\text { Jaundice, stomach } \\
\text { disorders, skin ulcers, } \\
\text { seminal weakness [16] }\end{array}$ \\
\hline $\begin{array}{l}\text { Zea mays L. } \\
\text { GA20181016NP094 }\end{array}$ & Makai $(\mathrm{N})$ & C & $\mathrm{Fr}$ & vet & $\begin{array}{l}\text { Corn flour is mixed with Asparagus racemosus root } \\
\text { juice and the mixture is given to buffaloes for about } \\
2-3 \text { days to stimulate milk production. }\end{array}$ & & \\
\hline \multicolumn{8}{|l|}{ Polypodiaceae } \\
\hline $\begin{array}{l}\text { Nephrolepis cordifolia (L.) C. } \\
\text { Presl } \\
\text { GA20181014NP073 }\end{array}$ & Tui amala (T) & $\mathrm{W}$ & $\mathrm{R}$ & food & $\begin{array}{c}\text { Watery root tubers are eaten as a snack to reduce } \\
\text { thirst. }\end{array}$ & {$[24]$} & Bone fractures [26] \\
\hline
\end{tabular}


Table 2. Cont

\begin{tabular}{|c|c|c|c|c|c|c|c|}
\hline $\begin{array}{l}\text { Family Scientific Name } \\
\text { Voucher Number }\end{array}$ & Vernacular Name $^{a}$ & Origin $^{b}$ & Parts Used ${ }^{\mathrm{c}}$ & Ethnobotanical Uses ${ }^{d}$ & Uses Description & $\begin{array}{c}\text { Similar Uses } \\
\text { References }\end{array}$ & Other Uses References \\
\hline \multicolumn{8}{|l|}{ Pteridaceae } \\
\hline $\begin{array}{l}\text { Hemionitis anceps (Blanf.) } \\
\text { Christenh. (=Cheilanthes } \\
\text { anceps Blanf.) } \\
\text { GA20171111NP040 }\end{array}$ & Rani sinka $(\mathrm{T})$ & $\mathrm{W}$ & $\mathrm{St} / \mathrm{L}$ & med/gast & $\begin{array}{l}\text { The plant is cleaned, boiled for about } 10 \text { min and } \\
\text { consumed } 3 \text { times a day (morning, afternoon, } \\
\text { evening) for 5-6 days, } 10 \text { days maximum, in case of } \\
\text { stomach problems. }\end{array}$ & & \\
\hline \multicolumn{8}{|l|}{ Ranunculaceae } \\
\hline $\begin{array}{l}\text { Clematis buchananiana DC. } \\
\text { GA20181015NP086 }\end{array}$ & Chyanmangre ( $\mathrm{T}$ ) & $\mathrm{W}$ & $\begin{array}{l}\mathrm{St} / \mathrm{R} \\
\mathrm{Wp}\end{array}$ & $\begin{array}{l}\text { med/resp,gast } \\
\text { food }\end{array}$ & $\begin{array}{l}\text { The plant is crushed, wrapped in a cloth, and } \\
\text { inhaled to treat sinusitis and allergic rhinitis. } \\
\text { Root juice is drunk to cure gastric problems. } \\
\text { The plant mixed with Blumea aromatica and Oryza } \\
\text { sativa, is left to ferment for a week, obtaining a } \\
\text { popular alcoholic beverage, "chhaang". }\end{array}$ & & \\
\hline \multicolumn{8}{|l|}{ Rosaceae } \\
\hline $\begin{array}{l}\text { Rubus ellipticus Sm. } \\
\text { GA20181014NP078 }\end{array}$ & $\begin{array}{c}\text { Aniselu (N), Polang } \\
\text { (T) }\end{array}$ & $\mathrm{W}$ & $\begin{array}{c}\mathrm{R} \\
\mathrm{Wp}\end{array}$ & $\begin{array}{c}\text { med/resp,gast } \\
\text { med/derm }\end{array}$ & $\begin{array}{l}\text { The hand-crushed root is inhaled to treat rhinitis and } \\
\text { sinusitis. The root juice is taken for gastric problems. } \\
\text { The crushed plant, mixed with Osbeckia nepalensis, is } \\
\text { applied on skin infections. }\end{array}$ & {$[19,24-27]$} & Typhoid [19], fever $[24,25]$ \\
\hline \multicolumn{8}{|l|}{ Rutaceae } \\
\hline $\begin{array}{l}\text { Aegle marmelos (L.) Corrêa } \\
\text { GA20181012NP056 }\end{array}$ & $\operatorname{Bel}(\mathrm{N})$ & $\mathrm{W}$ & $\mathrm{Fr}$ & $\begin{array}{c}\text { food } \\
\text { med/gast,fev }\end{array}$ & $\begin{array}{l}\text { Ripe fruits are consumed or mixed with cold water } \\
\text { to prepare a refreshing drink (sarbat). } \\
\text { Ripe fruits are consumed to treat diarrhoea and } \\
\text { fever. }\end{array}$ & {$[20,23,26]$} & $\begin{array}{l}\text { Scabies and roundworm } \\
\text { [23], diabetes [24] }\end{array}$ \\
\hline $\begin{array}{l}\text { Boenninghausenia albiflora } \\
\text { (Hook.) Rchb. ex Meisn. } \\
\text { GA20171111NP039 }\end{array}$ & Thangkap mra (T) & $\mathrm{W}$ & $\mathrm{Wp}$ & $\begin{array}{l}\mathrm{med} / \mathrm{fev} \\
\mathrm{med} / \mathrm{nerv}\end{array}$ & $\begin{array}{l}\text { Plant juice or boiled plant is taken 2-3 times a day } \\
\text { (preferably in the morning) in the treatment of fever, } \\
\text { until remission of symptoms. } \\
\text { In case of headache, the crushed plant is applied on } \\
\text { the forehead, inhaled, or fumigated. }\end{array}$ & & Cold, insect repellent [27] \\
\hline $\begin{array}{l}\text { Citrus } \times \text { limon (L.) Osbeck } \\
\text { GA20181013NP062 }\end{array}$ & Nibuwa (T) & C & $\mathrm{Fr}$ & $\begin{array}{c}\text { food } \\
\text { med/ant,ENT,fev }\end{array}$ & $\begin{array}{l}\text { It is used as a flavoring. } \\
\text { The Citrus } \times \text { limon juice, mixed with the dry and } \\
\text { pulverized bark of Bauhinia variegata, is applied on } \\
\text { the snake bites and the part is bandaged. } \\
\text { Lemon juice, mixed with the dry and pulverized } \\
\text { bark of Myrica esculenta, is used to clean the teeth in } \\
\text { case of toothache. } \\
\text { Lemon juice, mixed with the powder of Melia } \\
\text { azedarach bark, is used for the treatment of fever. }\end{array}$ & & Cholera [26] \\
\hline
\end{tabular}


Table 2. Cont

\begin{tabular}{|c|c|c|c|c|c|c|c|}
\hline $\begin{array}{l}\text { Family Scientific Name } \\
\text { Voucher Number }\end{array}$ & Vernacular Name ${ }^{a}$ & Origin $^{b}$ & Parts Used ${ }^{c}$ & Ethnobotanical Uses ${ }^{d}$ & Uses Description & $\begin{array}{c}\text { Similar Uses } \\
\text { References }\end{array}$ & Other Uses References \\
\hline $\begin{array}{l}\text { Citrus } \times \text { sinensis (L.) Osbeck } \\
\text { GA20171111NP041 }\end{array}$ & Junar $(\mathrm{T})$ & C & $\mathrm{Fr}$ & $\begin{array}{c}\text { food } \\
\text { med/gast,urogen }\end{array}$ & $\begin{array}{l}\text { The ripe fruits are eaten, sometimes with chilly } \\
\text { pepper. } \\
\text { In case of hepatic and renal stones, } 1-2 \text { fruits are } \\
\text { eaten a day, in small pieces during the day, for } \\
15 / 25 / 30 \text { days. }\end{array}$ & & \\
\hline \multicolumn{8}{|l|}{ Santalaceae } \\
\hline $\begin{array}{l}\text { Osyris lanceolata Hochst. \& } \\
\text { Steud. GA20171110NP035 }\end{array}$ & Borsajini (T) & $\mathrm{N}$ & $\begin{array}{c}\mathrm{St} \\
\mathrm{St} / \mathrm{Br}\end{array}$ & $\begin{array}{c}\text { food } \\
\mathrm{med} / \mathrm{musc}\end{array}$ & $\begin{array}{l}\text { The stem portion near the ground is used to prepare } \\
\text { a tea-like beverage. } \\
\text { Used for dislocations and limb sprains. The stem } \\
\text { portion near the ground is cut into small pieces, } \\
\text { boiled for more than } 3 \mathrm{~h} \text { adding water; the filtered } \\
\text { liquid is applied on the limbs banded with "Nepali } \\
\text { paper". The bandage is changed regularly for about } \\
\text { one month. In case of bone fractures, the bark is cut } \\
\text { into small pieces, boiled (even for more than } 3 \mathrm{~h} \text {, } \\
\text { sometimes together with bark of Senegalia catechu } \\
\text { and Albizia julibrissin, applied on the injured part } \\
\text { and banded with "Nepali paper". }\end{array}$ & {$[17,19]$} & Maternity problem [19] \\
\hline $\begin{array}{l}\text { Viscum articulatum Burm. f. } \\
\text { GA20171109NP028 }\end{array}$ & Khakhre bali (T) & $\mathrm{W}$ & $\mathrm{Wp}$ & $\mathrm{med} / \mathrm{musc}$ & $\begin{array}{l}\text { The crushed plant is applied on bone fractures and } \\
\text { the part is banded with strips obtained from the } \\
\text { Urtica dioica stem. }\end{array}$ & [24] & \\
\hline \multicolumn{8}{|l|}{ Sapotaceae } \\
\hline $\begin{array}{c}\text { Diploknema butyracea (Roxb.) } \\
\text { H.J.Lam } \\
\text { GA20181015NP089 }\end{array}$ & Chyuri (N) & $\mathrm{W}$ & $\begin{array}{l}\mathrm{Fr} \\
\mathrm{Br}\end{array}$ & med/derm,vet,fev & $\begin{array}{l}\text { The crushed ripe fruits are applied externally for } \\
\text { skin problems in humans and cattle. } \\
\text { The bark of stem portion near the ground is dried, } \\
\text { reduced to powder, mixed, and drunk with water or } \\
\text { milk, to cure fever. }\end{array}$ & & \\
\hline \multicolumn{8}{|l|}{ Saxifragaceae } \\
\hline $\begin{array}{l}\text { Bergenia ciliata (Haw.) } \\
\text { Sternb. } \\
\text { GA20181017NP109 }\end{array}$ & $\begin{array}{l}\text { Pashanved (N), Bra } \\
\text { mindhu (T) }\end{array}$ & $\mathrm{W}$ & $\mathrm{Rh}$ & med/gast,fev & $\begin{array}{l}\text { Rhizome juice is drunk to treat stomach problems or } \\
\text { the dried rhizome is chewed like candy throughout } \\
\text { the day also to cure fever. }\end{array}$ & {$[16,19,24]$} & $\begin{array}{l}\text { Piles, tumor, urinary } \\
\text { problems, hearth, and } \\
\text { respiratory diseases [16], } \\
\text { maternity problem [17], } \\
\text { back pain [25] }\end{array}$ \\
\hline \multicolumn{8}{|l|}{ Simaroubaceae } \\
\hline $\begin{array}{l}\text { Picrasma quassioides (D. Don) } \\
\text { Benn. } \\
\text { GA20181018NP115 }\end{array}$ & Nim kath (N) & $\mathrm{W}$ & Wood & med/fev,ant,musc,nerv & $\begin{array}{l}\text { A typical recipe }\left(^{*}\right) \text { is used to cure fever, internal } \\
\text { fever, food poisoning, joint pain, migraine. }\end{array}$ & & \\
\hline
\end{tabular}


Table 2. Cont.

\begin{tabular}{|c|c|c|c|c|c|c|c|}
\hline $\begin{array}{l}\text { Family Scientific Name } \\
\text { Voucher Number }\end{array}$ & Vernacular Name $^{a}$ & Origin $^{b}$ & Parts Used $^{c}$ & Ethnobotanical Uses ${ }^{d}$ & Uses Description & $\begin{array}{l}\text { Similar Uses } \\
\text { References }\end{array}$ & Other Uses References \\
\hline \multicolumn{8}{|l|}{ Solanaceae } \\
\hline $\begin{array}{l}\text { Solanum nigrum } \mathrm{L} \text {. } \\
\text { GA20181012NP053 }\end{array}$ & Camai $(\mathrm{T})$ & $\mathrm{W}$ & Fr & med/ENT,card & $\begin{array}{l}\text { Ripe fruits are consumed as much as possible, in } \\
\text { case of tongue infections and piles. }\end{array}$ & & $\begin{array}{l}\text { Headache [23], wounds [24] } \\
\text { malnutrition in children [26] }\end{array}$ \\
\hline \multicolumn{8}{|l|}{ Thymelaceae } \\
\hline $\begin{array}{l}\text { Daphne bholua Buch.-Ham. } \\
\text { ex D. Don } \\
\text { GA20171110NP031 }\end{array}$ & Lokta $(\mathrm{N})$ & C & $\mathrm{Br}$ & $\begin{array}{c}\text { handicr } \\
\text { med/derm,ant,ENT,musc }\end{array}$ & $\begin{array}{l}\text { The bark is used to make "Nepali paper". } \\
\text { "Nepali paper" is used to make bandages in case of } \\
\text { skin problems, snake bites, bone fractures, swelling } \\
\text { of the dental glands. }\end{array}$ & {$[16]$} & $\begin{array}{l}\text { Fever, intestinal disorders, } \\
\text { and parasites [16], sinusitis } \\
{[\text { [19] }}\end{array}$ \\
\hline \multicolumn{8}{|l|}{ Urticaceae } \\
\hline $\begin{array}{l}\text { Boehmeria virgata (G.Forst.) } \\
\text { Guill. subsp. macrophylla } \\
\text { (Hornem.) Fris \& } \\
\text { Wilmot-Dear. (=Boehmeria } \\
\text { macrophylla Hornem.) } \\
\text { GA20171101NP016 } \\
\end{array}$ & Chalnesisnu (N) & $\mathrm{W}$ & $\mathrm{L}$ & vet & Leaves are nutritious cattle fodder. & [16] & Cuts and wounds $[16,23]$ \\
\hline $\begin{array}{l}\text { Boehmeria rugulosa Wedd. } \\
\text { GA20171101NP015 }\end{array}$ & Bhlan chhing $(\mathrm{T})$ & $\mathrm{W}$ & $\begin{array}{c}\mathrm{Br} \\
\text { Wood }\end{array}$ & $\begin{array}{c}\text { food } \\
\text { handicr }\end{array}$ & $\begin{array}{l}\text { Powdered bark is mixed with flour to make the } \\
\text { bread softer and tastier. } \\
\text { Wood is used for the production of religious masks } \\
\text { and teki, container where butter (ghee) and yogurt } \\
\text { are prepared. }\end{array}$ & [16] & $\begin{array}{l}\text { Cuts and wounds, body } \\
\text { pain [16] }\end{array}$ \\
\hline $\begin{array}{c}\text { Urtica dioica L. } \\
\text { GA20171109NP027 }\end{array}$ & Sisnu $(\mathrm{N})$ & $\mathrm{W}$ & St & $\mathrm{med} / \mathrm{musc}$ & $\begin{array}{l}\text { Some strips obtained from the stem are used to } \\
\text { wrap the limbs affected by bone fracture in } \\
\text { association with the Viscum articulatum. }\end{array}$ & {$[17,26,27]$} & $\begin{array}{c}\text { Galactogogue, diabetes, } \\
\text { high pressure [17], fever, } \\
\text { asthma, toothache, } \\
\text { paralysis, uterine bleeding } \\
\text { [19], rheumatism [25] }\end{array}$ \\
\hline \multicolumn{8}{|l|}{ Verbenaceae } \\
\hline $\begin{array}{l}\text { Lantana camara L. } \\
\text { GA20171101NP019 }\end{array}$ & Polung (T) & $\mathrm{N}$ & Fr & food & Ripe black fruits are eaten by children as snack. & & \\
\hline \multicolumn{8}{|l|}{ Xanthorrhoeaceae } \\
\hline $\begin{array}{l}\text { Aloe vera (L.) Burm.f. } \\
\text { GA20171109NP024 }\end{array}$ & Ghyukumari (N) & $\mathrm{C}$ & $\mathrm{L}$ & med/derm,met,gast & $\begin{array}{l}\text { The leaves are rubbed on burned skin. } \\
\text { To treat jaundice, the leaf juice, or the filtered liquid } \\
\text { of the leaves, crushed and boiled for 2-3 minutes is } \\
\text { drunk. } \\
\text { Some pieces of leaves are eaten in case of lack of } \\
\text { appetite. } \\
\text { Flowers are used as an ornamental decoration. }\end{array}$ & {$[19,20,26,27]$} & Cuts and wounds $[23,24]$ \\
\hline
\end{tabular}


Table 2. Cont

\begin{tabular}{|c|c|c|c|c|c|c|}
\hline $\begin{array}{c}\text { Family Scientific Name } \\
\text { Voucher Number }\end{array}$ & Vernacular Name $^{a}$ & Origin $^{b}$ & Parts Used ${ }^{c}$ & Ethnobotanical Uses ${ }^{d}$ & $\begin{array}{c}\text { Similar Uses } \\
\text { References }\end{array}$ & Other Uses References \\
\hline \multicolumn{7}{|l|}{ Zingiberaceae } \\
\hline $\begin{array}{l}\text { Cautleya spicata (Sm.) Baker } \\
\text { GA20171110NP030 }\end{array}$ & $\begin{array}{l}\text { Pahelo Ausadhi (N) } \\
\text { Jungli haldi (T) }\end{array}$ & $\mathrm{W}$ & $\mathrm{Rh}$ & med/gast,urogen & $\begin{array}{l}\text { Rhizome juice is drunk once a day (morning) to } \\
\text { treat constipation (kabjiat) and kidney stones. In case } \\
\text { of gastric disorders, the juice is drunk once a week. } \\
\text { Sometimes a second dose may be needed. }\end{array}$ & Conjunctivitis [26] \\
\hline $\begin{array}{l}\text { Curcuma angustifolia Roxb. } \\
\text { GA20181013NP063 }\end{array}$ & $\begin{array}{c}\text { Jangali Haldi, } \\
\text { Jangali Besar (N) }\end{array}$ & C & $\mathrm{Rh}$ & med/resp & $\begin{array}{l}\text { Fumigations with powdered rhizome are useful to } \\
\text { cure cold. }\end{array}$ & $\begin{array}{l}\text { Cuts and wounds [24], } \\
\text { stomach problems [26] }\end{array}$ \\
\hline $\begin{array}{l}\text { Curcuma caesia Roxb. } \\
\text { GA20181017NP102 }\end{array}$ & Mlang haldi (T) & C & $\begin{array}{l}\mathrm{Rh} \\
\mathrm{R}\end{array}$ & med/gast,mat & $\begin{array}{l}\text { Used in case of loss of appetite. The cleaned } \\
\text { rhizome is crushed and the juice is drunk with the } \\
\text { addition of water, twice a day for } 2 \text { days. } \\
\text { The root juice is drunk to treat postpartum bleeding. }\end{array}$ & Back pain [25] \\
\hline $\begin{array}{l}\text { Curcuma longa L. } \\
\text { GA20181013NP064 }\end{array}$ & Haldi, Besar (N) & C & $\mathrm{Rh}$ & $\mathrm{med} / \mathrm{met}, \mathrm{fev}$ & $\begin{array}{l}\text { The raw rhizome is eaten to cure diabetes. The } \\
\text { powdered rhizome is used for fumigations in case of } \\
\text { fever. }\end{array}$ & $\begin{array}{l}\text { Cough/cold, tonsillitis, } \\
\text { swellings [16], gastritis [25] }\end{array}$ \\
\hline $\begin{array}{l}\text { Zingiber officinale Roscoe } \\
\text { GA20181015NP083 }\end{array}$ & Aduwa (N) & C & $\mathrm{Rh}$ & $\mathrm{med} / \mathrm{met}$ & $\begin{array}{l}\text { To cure goiter, the dried rhizome powder is mixed } \\
\text { with the Bauhinia variegata bark powder and water, } \\
\text { and applied to the throat twice a day (morning and } \\
\text { evening). }\end{array}$ & $\begin{array}{l}\text { Diarrhoea, sinusitis [23], } \\
\text { cold and cough [27] }\end{array}$ \\
\hline
\end{tabular}


The taxonomic diversity percentage was calculated: the most representative species belonged to Asteraceae (10.34\%), Fabaceae (6.03\%), Lamiaceae (5.17\%) and Zingiberaceae (4.31\%) (Table 3).

Table 3. Taxonomic diversity of recorded plants species.

\begin{tabular}{ccc}
\hline Family & Number of Species & Percent Value \\
\hline Asteraceae & 12 & 10.34 \\
Fabaceae & 7 & 6.03 \\
Lamiaceae & 6 & 5.17 \\
Zingiberaceae & 5 & 4.31 \\
Amaranthaceae & 4 & 3.45 \\
Poaceae & 4 & 3.45 \\
Rutaceae & 4 & 3.45 \\
Anacardiaceae & 3 & 2.59 \\
Apocynaceae & 3 & 2.59 \\
Araceae & 3 & 2.59 \\
Euphorbiaceae & 3 & 2.59 \\
Lauraceae & 3 & 2.59 \\
Meliaceae & 3 & 2.59 \\
Urticaceae & 3 & 2.59 \\
Other 43 families & 53 & 45.58 \\
Total: 57 & $\mathbf{1 1 6}$ & $\mathbf{1 0 0}$ \\
\hline
\end{tabular}

Among them the most representative were herbs (36.20\%), followed by trees $(26.72 \%)$, shrubs $(25 \%)$, climbers $(8.62 \%)$ and parasitic plants species (1.72\%); further, two ferns were also recorded $(1.72 \%)$. These data are indicative of the richness of the local flora and testify the botanical knowledge of the informants, in accordance with previous studies conducted in Central Nepal [28,29].

\subsection{Ethnomedicinal Uses of Plants}

About $87 \%$ of the 116 species (101) was reported for medicinal purposes, with 271 citations of uses. Among these species, 20 were reported also in other categories, particularly as food and food/medicine (11) and religious/ritual (6). Minor uses concerned domestic, handcraft, and agropastoral categories. The plants used were mostly wild plants easy to find, in particular, herbs, trees and shrubs growing near villages. Sometimes even some cultivated plants were used for medicinal purposes (Figure 1A).

More rarely, hard-to-find plants were also selected, such as Viscum articulatum, Piper retrofractum and Picrasma quassioides that grow in inaccessible areas of the forest (Figure 1B). Medicinal plants were used by informants to treat 13 categories of human ailments and 1 related to cattle diseases (Table 4); 48 species were used to treat only one disease (e.g., Ficus semicordata, Figure 1C) and 53 species to treat more than one ailment (e.g., Oxalis corniculata, Figure 1D).

The most frequent disease categories treated with medicinal plants and showing the highest citations, were those concerning fever, digestive system, skeletal and muscular system, and skin diseases (56, 45, 30 and 25 citations, respectively). Traditional healers identified the diseases according to traditional patient examination, including inspection of tongue, skin, throat, eyes (red eyes, yellow eyes, etc.), feces, urine, external features (i.e., swelling), bleeding, body temperature.

Despite recent influences from Western medicine, ethnic people continue to rely on traditional medicine. This seems to confirm the therapeutic efficacy of local plants for the treatment of the most common and widespread pathologies [30]. 


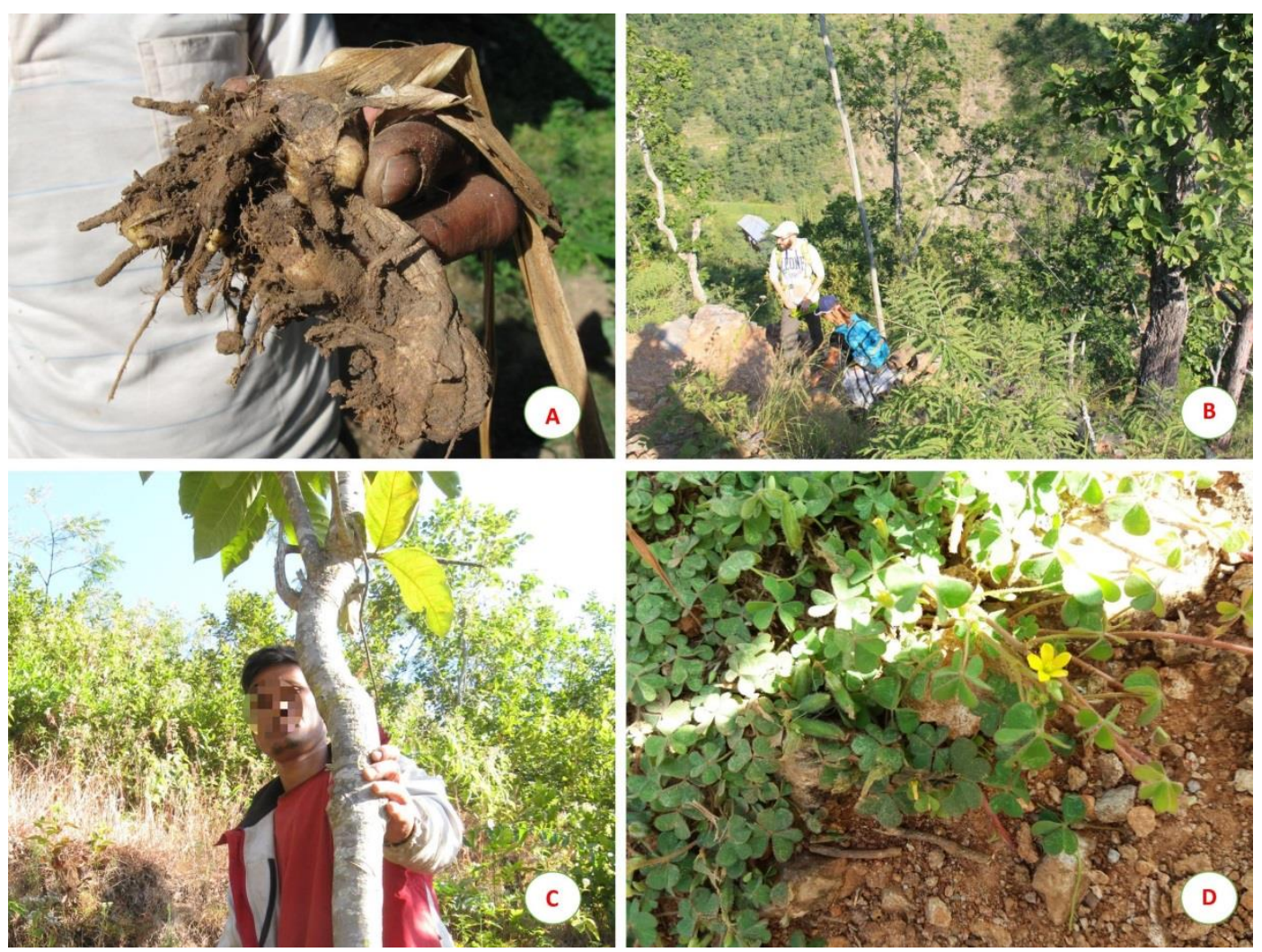

Figure 1. (A) Rhizome of Cautleya spicata; (B) Medicinal plants search during a jungle walk around Mukpatar village; (C) Ficus semicordata used for gastric problems; (D) Oxalis corniculata, remedy for the treatment of various diseases.

Table 4. Ailments included in each illness category.

\begin{tabular}{|c|c|c|}
\hline Illness Category & Ailments & Number of Citations \\
\hline Fever & $\begin{array}{c}\text { Fever, high fever, malarial fever, typhoid fever, "internal" fever (feeling } \\
\text { of higher level of heat inside the body) }\end{array}$ & 56 \\
\hline Gastrointestinal & $\begin{array}{l}\text { Stomach diseases, gastritis, vomiting, indigestion, loss of appetite, } \\
\text { diarrhoea, dysentery, constpation (kabjiat), liver stones, abdominal pain, } \\
\text { blood stool, flatulence }\end{array}$ & 45 \\
\hline Musculoskeletal & $\begin{array}{l}\text { Rheumatism, body pain, joint pain, joint trauma, joint swelling, ankle } \\
\text { sprains, bone fracture, sprains of the limbs }\end{array}$ & 30 \\
\hline Dermatological & $\begin{array}{c}\text { Skin diseases, skin infections, cuts, wounds, pimples, boils, itchy } \\
\text { pustules, burns }\end{array}$ & 25 \\
\hline Antidote & Food and drink poisoning, snake bites & 19 \\
\hline Respiratory diseases & $\begin{array}{c}\text { Cough, cold, cooling diseases, sinusitis, rhinitis, throat irritations, } \\
\text { breathing problems }\end{array}$ & 17 \\
\hline $\begin{array}{l}\text { Oral, dental, ENT (ear, nose, } \\
\text { and throat) }\end{array}$ & $\begin{array}{l}\text { Gums problem, mouth swelling, mouth infections, dry mouth, swelling } \\
\text { of the dental glands, toothache, tongue infections, eye diseases, "red } \\
\text { eyes" (conjunctivitis), nose swelling, ear infections, earaches }\end{array}$ & 15 \\
\hline Metabolic & Blood purification, jaundice, diabetes, goiter & 15 \\
\hline Nervous system & Migraine, headache, anxiety, insomnia & 14 \\
\hline Maternal ailments & $\begin{array}{l}\text { Difficulty in childbirth, infertility, menstrual disorders, postpartum } \\
\text { bleeding }\end{array}$ & 11 \\
\hline Urogenital & Urinary problems, bladder swelling, blood in the urine, kidney stones & 9 \\
\hline Cardiovascular diseases & High blood pressure, blood circulation disorders, heart attack, piles & 6 \\
\hline General health & Cancer, weakness, fatigue & 2 \\
\hline Veterinary & $\begin{array}{c}\text { Skin problems in cattle, reduced milk (agalactia) in buffaloes, general } \\
\text { weakness }\end{array}$ & 7 \\
\hline Total & 14 & 271 \\
\hline
\end{tabular}




\subsection{Herbal Remedies}

For medicinal preparations, roots, and rhizomes $(23.61 \%)$, whole plant $(22.88 \%)$, followed by bark and fruits (about $10 \%$ respectively) were used (Table 5).

Table 5. Plant parts used in the preparation of medicine.

\begin{tabular}{ccc}
\hline Plant Parts & Use Citations & $\mathbf{\%}$ \\
\hline Root/Rhizome & 64 & 23.61 \\
Whole plant & 62 & 22.88 \\
Bark & 27 & 9.96 \\
Fruits & 27 & 9.96 \\
Seeds & 19 & 7.01 \\
Leaves & 18 & 6.64 \\
Flowers & 17 & 6.27 \\
Stem & 14 & 5.16 \\
Latex & 10 & 3.69 \\
Young shoots & 8 & 2.95 \\
Wood & 5 & 1.84 \\
Total & $\mathbf{2 7 1}$ & $\mathbf{1 0 0}$ \\
\hline
\end{tabular}

The preference in selecting portions of plants could be related both to their availability during the year and to the higher concentration of active ingredients. For example, most informants considered the part of the stem closest to the ground or underground portions more effective from a therapeutic point of view. The preferential use of roots and rhizomes was also reported by Bhattarai [31] in its ethnobotanical survey carried out in Ilam District, Eastern Nepal. On the contrary, the study of Luitel et al. [26] in the Makwanpur District of Central Nepal found that the most frequent portions used for medicinal purposes were fruits/seeds, followed by whole plants and leaves.

Considering only the 98 plant species used in human ailments, the informants reported various medicinal preparation forms. These were based on a single plant or were polyherbal formulations, fresh juice was the preferred form $(36.27 \%)$ due to the simplicity of preparation by crushing the plant in a stone mortar and because this was also an excellent way of getting vitamins and minerals from the plant. The juice had to be taken within a short time after being prepared. Even raw plants $(13.72 \%)$ were eaten for therapeutic purposes, especially roots, fruits, seeds, and tubers. Herbal poultices (13.72\%) included "poultice"-generally prepared by crushing the plant portions to a pulpy mass - and "compresses" made of a piece of cloth soaked in the plant decoction or infusion. Other preparation forms were direct application $(10.78 \%)$, herbal teas $(7.84 \%)$, including decoction and infusion, inhalation $(5.88 \%)$, powder $(4.9 \%)$, vegetable used as food-medicine $(2.94 \%)$, ointment $(1.96 \%)$, maceration and smoke (0.98\%, respectively) (Figure 2$)$.

The informants generally preferred fresh plants because they found them more effective. Plant parts were generally prepared using hot or cold water as a solvent, but other solvents such as milk, honey, lemon juice and rapeseed oil were occasionally employed.

Single herbs, or multiple herbs combined to obtain original recipes, can be used. Particularly, a Newar medicinal recipe, used to treat various ailments, was found to be in practice. It is prepared with aerial parts of Artemisia indica, Centella asiatica, Drymaria cordata, Mentha spicata, Oxalis corniculata (Figure 1D), Tagetes erecta, seeds of Oroxylum indicum, sprouts dried of Oryza sativa, wood of Picrasma quassioides and limestone powder. A typical feature of Newari medicine is that different medicinal plants can be used to treat a number of diseases [32].

Herbal remedies for human ailments were administered through different routes: internal use $(66.33 \%)$, topical application (23.47\%), nasal application and others $(10.2 \%)$.

The prescribed quantity was always approximate, depending on how the healer judged the severity of the disease. The frequency of taking the medicines has been described in terms of the number of times in a day and the duration as for number of days or weeks. 


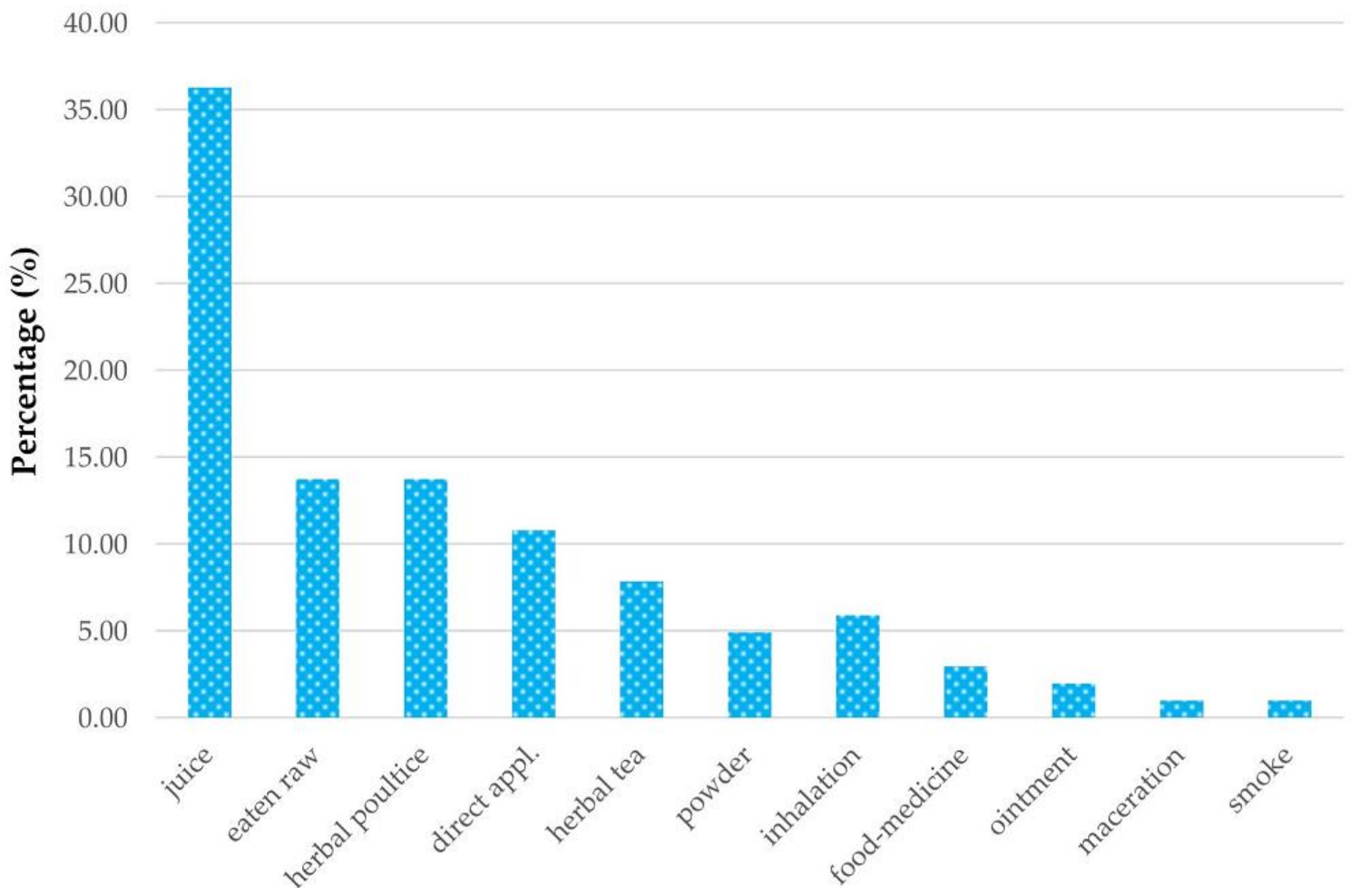

Figure 2. Histogram of the relative frequencies of the medicinal preparation forms used.

\subsection{Data Analysis}

To evaluate the ethnopharmacological importance of each plant species and the degree of agreement among informants some ethnobotanical indices were calculated. The informant consensus factor (Fic) was used to highlight medicinal plants of particular cultural relevance and the degree of agreement of informants about each category of ailments. The different ailments and diseases were classified into 14 categories (see Table 4 ) and a Fic value for each category was calculated. The results showed that fever category had the greatest agreement (0.49), followed by gastrointestinal and dermatological categories (0.29). Intermediate agreement among informants was recorded for metabolic, oral/dental/ENT (0.28) and musculoskeletal (0.21) categories, while the others had a Fic lower than 0.20 (Table 6).

Table 6. Informants consensus factor (Fic) by categories of diseases, calculated only for several use reports $\geq 15$.

\begin{tabular}{cccc}
\hline Disease Category & Use Reports (Nur) & Number of Taxa (Nt) & Fic \\
\hline Fever & 56 & 29 & 0.49 \\
\hline Gastrointestinal & 45 & 32 & 0.29 \\
\hline Dermatological & 25 & 18 & 0.29 \\
\hline Metabolic & 15 & 11 & 0.28 \\
\hline Oral dental ENT & 15 & 11 & 0.28 \\
\hline $\begin{array}{c}\text { Musculoskeletal } \\
\text { problems }\end{array}$ & 30 & 24 & 0.21 \\
\hline Antidote & 20 & 17 & 0.16 \\
\hline Respiratory diseases & 17 & 15 & 0.13 \\
\hline
\end{tabular}

The fidelity level (FL) was used to identify the most preferred species for treating certain ailments, showing that the most quoted species were Calotropis gigantea $(100 \%)$ for 
dermatological diseases, Drymaria cordata (100\%) against fever, Mangifera indica and Wrightia arborea $(100 \%)$ for gastrointestinal disorders. For treatment of fever also Oxalis corniculata and Centella asiatica were reported, with a FL of $80 \%$ and $75 \%$, respectively. Notably a FL of $75 \%$ was also found for Curcuma caesia for treatment of maternal ailments. To better underline the therapeutic properties of the most cited medicinal plants, we have reported some information on their main chemical compounds probably involved in the specific curative effect (Table 7), based on recent pharmacological investigations [33-39].

Table 7. Fidelity level (FL) value of medicinal plants against a given ailment category and main chemical compounds allegedly responsible for the therapeutic effects.

\begin{tabular}{|c|c|c|c|c|c|}
\hline Medicinal Plant & Therapeutic Category & $\mathbf{N}_{\mathrm{p}}$ & $\mathbf{N}$ & FL Value (\%) & Main Chemical Constituents \\
\hline Calotropis gigantea & Dermatological & 5 & 5 & 100 & $\begin{array}{l}\text { Lupeol present in the latex, with wound } \\
\text { healing and antimicrobial properties [33]. }\end{array}$ \\
\hline Drymaria cordata & Fever & 5 & 5 & 100 & $\begin{array}{c}\text { Saponins and related phytosterols, as well } \\
\text { as phenols have been associated with } \\
\text { antipyretic activity [34]. }\end{array}$ \\
\hline Mangifera indica & Gastrointestinal & 3 & 3 & 100 & $\begin{array}{l}\text { Polyphenols and flavonoids from peel fruit } \\
\text { with antinflammatory and antioxidant } \\
\text { activities [35]. }\end{array}$ \\
\hline Wrightia arborea & Gastrointestinal & 3 & 3 & 100 & Not known. \\
\hline Oxalis corniculata & Fever & 4 & 5 & 80 & $\begin{array}{l}\text { Phenolic compounds with antibacterial } \\
\text { activity [36]. }\end{array}$ \\
\hline Centella asiatica & Fever & 3 & 4 & 75 & $\begin{array}{c}\text { Asiaticoside (triterpenoid) with antipyretic } \\
\text { effects [37]. }\end{array}$ \\
\hline Curcuma caesia & Maternal ailments & 3 & 4 & 75 & Saponins with coagulating properties [38]. \\
\hline Achyranthes bidentata & Maternal ailments & 4 & 9 & 44 & $\begin{array}{l}\text { antioxidant effects and promoting blood } \\
\text { circulation [39]. }\end{array}$ \\
\hline Achyranthes bidentata & Fever & 3 & 9 & 33 & $\begin{array}{c}\text { Saponins with antinflammatory and } \\
\text { antioxidant effects and promoting blood } \\
\text { circulation [39]. }\end{array}$ \\
\hline
\end{tabular}

Plant species with highest relative frequency of citation (RFCs) were Achyranthes bidentata (0.28), Calotropis gigantea and Drymaria cordata (0.16), followed by Artemisia indica, Centella asiatica, Curcuma caesia, Daphne papyracea and Oxalis corniculata (0.13, respectively) (Table 8 ).

Table 8. Relative frequency of citation (RFCs) has been reported only for a value $\geq 0.1$.

\begin{tabular}{cc}
\hline Plant Species & RFCs \\
\hline Achyranthes bidentata & 0.28 \\
Calotropis gigantea & 0.16 \\
Drymaria cordata & 0.16 \\
Artemisia indica & 0.13 \\
Centella asiatica & 0.13 \\
Curcuma caesia & 0.13 \\
Daphne papyracea & 0.13 \\
Oxalis corniculata & 0.13 \\
\hline
\end{tabular}

\section{Discussion}

Our results were in good accordance with other ethnobotanical studies carried out in Nepal and more in general, with the heritage of Traditional Asian Medicine. For example, the use of the latex from Calotropis gigantea for treatment of dermatological diseases (FL 100\%) has been previously reported $[23,40,41]$. This plant is well-known in Ayurvedic medicine, reporting its many medicinal properties, including antimicrobial, antidiarrhoeal, antibacterial, antioxidant, anti-pyretic, and cytotoxic activities [42].

The antipyretic effects of Drymaria cordata (FL 100\%), previously reported [43], can be associated with its content in saponins and related phytosterols, as well as phenols [34]. In addition, our informants have referred another medicinal use of plant juice drunken for the treatment of rhinitis and sinusitis. 
The same use of this plant has also been indicated in other areas of Nepal, but in this case the remedy administration was carried out by inhalation or fumigations [44,45].

Mangifera indica is a common tree in the home gardens of villages. Our informants described the use of the ripe mango peel to treat various gastrointestinal disorders (FL 100\%). The use of this species for this category disease is confirmed by other studies on the folk medicine of Nepal [40], but bark and roots are generally the portions to which the greatest curative efficacy is attributed [23,46]. Therefore, the medicinal use of the fruit peel is typical of the survey area.

Another plant species showing 100\% FL indicated by our informants for gastrointestinal problems was Wrightia arborea (Figure 3A).
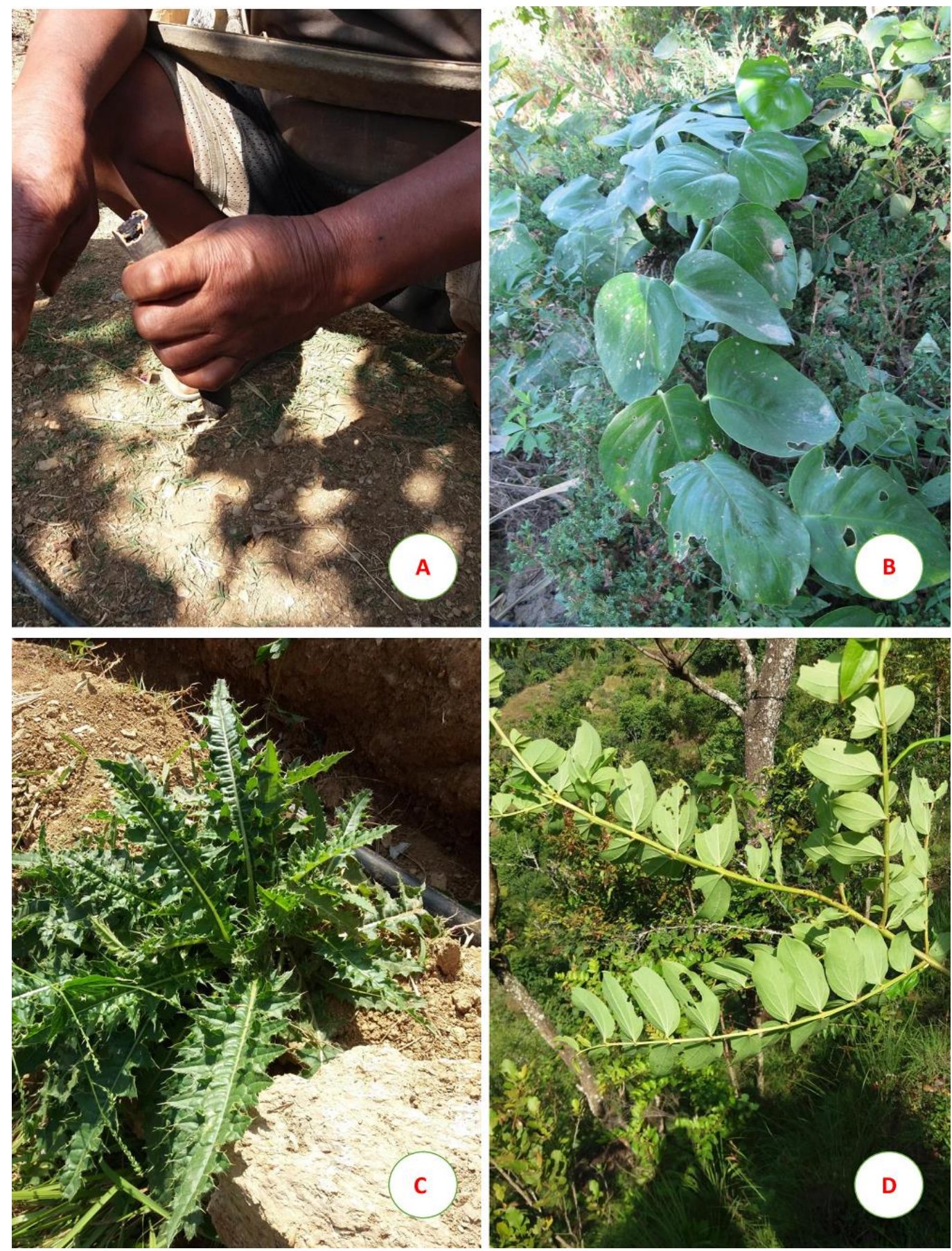

Figure 3. Informant with a pod of (A) Wrightia arborea; (B) Rhaphidophora glauca; (C) Cirsium wallichii; (D) Coriaria nepalensis. 
This plant, belonging to the Apocynaceae family, is widely used in Ayurveda, Siddha, and other traditional medicines to treat various human diseases [47]. The bark is used as an antidote against snake bites and scorpion stings, for curing menstrual and renal complaints and for its antipyretic and antibacterial activities. The root is used to bring relief in case of headache and fever, while the leaves as a diaphoretic, expectorant and to treat dysentery, toothache, and diarrhea [48,49]. In our survey, we found a previously unknown use of the W. arborea pod septum, consumed raw to cure intestinal disorders.

We also compared our data with those from previous studies conducted among ethnic communities living in hilly rural areas of the Kavrepalanchok District [16,17], and in neighboring districts of Central Nepal $[19,20,23-27]$. Such comparison (Table 2) revealed that 77 of the plant species $(66 \%)$ had already been mentioned and that 44 of them $(38 \%)$ had been indicated for similar uses in at least one case. Therefore, we have focused our attention on species or on unusual medicinal uses of plants that had not been referred previously.

Although mixing medicinal plants and minerals—like black salt, "chuna" (limestone powder) iron, copper, "silajeet" (Asphaltum punjabianum), alum, etc.-is a common practice among shamans and local healers (also for making "buti", or amulets) [50], in our survey we found some original recipes. For example, pieces of copper were added to the bark of Ficus semicordata to make a preparation for treating bloody diarrhea. Another special combination of plants and mineral powder was used by Newar healers against many diseases such as fever, joint pain and others. These plants included aerial parts from Centella asiatica, Tagetes patula, Mentha spicata, Oxalis corniculata, Drymaria cordata and Artemisia indica, seeds of Oroxylum indicum, dry shoots of Oryza sativa, and wood of Picrasma quassioides Notably, P. quassioides is not present in any of the previous studies on the ethnobotany of the Tamang people. Its wood contains quassinoids with anticancer and antimalarial activity [51], other than a number of medicinal compounds with anthelmintic, antiamoebal, antiviral, bitter, hypotensive, and stomachic properties [52].

Another interesting use was reported for Rhaphidophora glauca (Figure 3B), an aroid liane native to the subtropical and warm temperate Himalayan regions. The juice obtained from the aerial parts was administered to women to improve pregnancy. Similar uses are reported for related Indian species such as R. hookeri whose stem juice was indicated for pregnant women [53], and R. pertusa, that showed luteolytic, oestrogenic, and follicle-stimulating activities in cattle and buffaloes [54]. Interestingly, none of the previous studies on Tamang folk medicine cited this specific use for this genus. On the contrary, the most common medicinal use of different Rhaphidophora species, i.e., the treatment of bone fractures in human and cattle $[55,56]$, was not reported by our informants.

Arenaria benthamii, belonging to the Caryophyllaceae family, has been employed to fill pillows in case of cold and cough, and to reduce nasal mucus. Although the balsamic properties of this species and of other Caryophyllaceae, such as Gypsophila arrostii Guss. and G. oldhamiana Miq., are known [57], this route of administration had never been reported previously.

Another new finding concerns the use of root juice from Strobilanthes pentastemonoides for the treatment of high fever, while other studies only reported the use of this plant like fodder $[58,59]$.

The stem juice obtained from branchlets of Cipadessa baccifera was highly regarded by shamans as a good remedy for counteracting food and drink poisoning. This use had never been previously reported, but a few studies have shown the effectiveness of this plant as an antidote against snake, scorpion, and insect bites [60,61].

Our informants reported that the root juice of Cirsium wallichii (Figure 3C) was useful for urinary problems, weakness, and malarial fever. Other studies cited the root of this species to treat gastric problems [62], while recently this species has been investigated also for antimicrobial and antioxidant properties shown by leaf, inflorescence, and bark extracts [63].

The use of the ripe fruits and plant juice of Coriaria nepalensis (Figure 3D) in case of indigestion is unexpected, because the leaves and fruits of many Coriaria species are considered poisonous in Asia, due to the presence of coriamyrtin with convulsive effects [64]. Nevertheless, in Chinese Traditional 
Medicine this species is used to treat various diseases [65], and the leaf juice was indicated as antiseptic among the Newar community of Kathmandu District [32].

The Crassulacea Bryophyllum pinnatum (Figure 4A) was described by our informants as useful against kidney stones, in agreement with other studies [66-68].
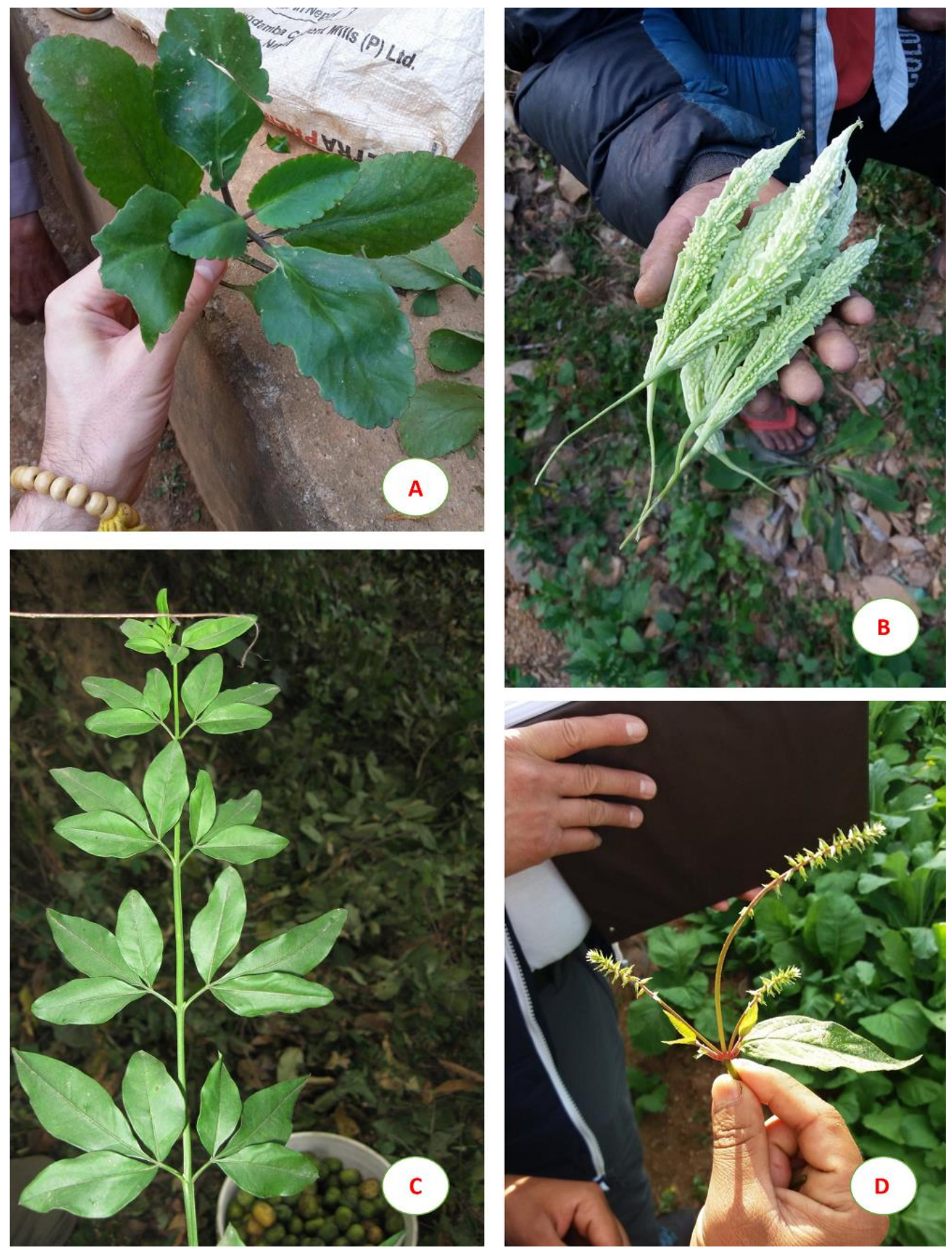

Figure 4. (A) Bryophyllum pinnatum; (B) Fruits of Momordica charantia; (C) Jasminum mesnyi; (D) Achyranthes bidentata.

Momordica charantia (Figure 4B) is commonly used in the traditional medicine of different developing countries for its multiple properties, especially as antidiabetic [69]. In our study, this plant was mainly used by local people to lower blood pressure. Such effect, also reported in African 
folk medicine, was tested on normal and diabetic rats showing that an aqueous extract possesses hypoglycaemic and hypotensive properties [70].

Jasminum mesnyi (Figure 4C), commonly known as Japanese jasmine, has been reported in our survey to cure fever and typhoid. The antimicrobial potential of the leaf extract of this species has been recently demonstrated on Gram-positive and Gram-negative bacterial pathogens [71].

Achyranthes bidentata, (Figure 4D) belonging to Amaranthaceae, is a well-known medicinal plant very common near the villages and used by local people to treat various diseases such as fever (FL about 33\%) and maternal ailments (FL about 44\%). Accordingly, this species showed the highest relative frequency of citation. These findings are a novelty, because a previous study on the same area reported only the use of this species for the treatment of urinary ailments [16].

Finally, twelve of the 116 plants cited by our informants are also traded in the streets of the Kathmandu Valley for the preparation of popular medicinal remedies, being a valuable source of income for local people [72]: Acorus calamus, Asparagus racemosus, Bergenia ciliata, Cautleya spicata, Curcuma angustifolia, Osyris wightiana, Phyllanthus emblica, Rubus ellipticus, Stephania glandulifera, Terminalia bellirica, Tinospora sinensis, and Valeriana jatamansi.

Some informants (especially plant traders) referred that there is a great demand of Asparagus racemosus roots, because they are useful for stimulating milk production in buffaloes. For this reason, the collection and trade of this species should be controlled to prevent environmental depletion.

\section{Materials and Methods}

\subsection{Study Area and Ethnic People}

The Bagmati Pradesh (State) of Nepal comprises 13 districts, namely Sindhuli, Ramechhap, Dolakha, Sindhupalchok, Kavrepalanchok, Lalitpur, Bhaktapur, Kathmandu, Nuwakot, Rasuwa, Dhading, Makwanpur and Chitwan Districts. At the time of the 2011 Nepal census, Kavrepalanchok District had a population of 381,937. Of these, 50.9\% spoke Nepali, 33.5\% Tamang, $11.1 \%$ Newari, 1.6\% Danuwar and 1.4\% Magar as their first language [9]. The Kavrepalanchok District is located between $85^{\circ} 24^{\prime}$ to $85^{\circ} 49^{\prime} \mathrm{E}$ and $27^{\circ} 22^{\prime}$ to $27^{\circ} 85^{\prime} \mathrm{N}$, with altitudes ranging from 275 (Dolalghat/Sunkoshi River) to $3018 \mathrm{~m}$ ASL (Bethanchowk hill). The total area is about $1396 \mathrm{~km}^{2}$ and the average temperature ranges from $10^{\circ}$ to $31^{\circ} \mathrm{C}$ [13]. This region has a subtropical climate and its vegetation is characterized by the forest of Schima sp., Castanopsis sp., Pinus roxburghii and Alnus nepalensis at the lower belt, while broad leaved oak forests of Quercus spp. are found at upper belt [73]. The Kavrepalanchok District consists of 13 Municipalities, out of which six are urban municipalities and seven are rural ones. The present survey was undertaken in six villages of the Temal Rural Municipality: Mukpatar $\left(27^{\circ} 28^{\prime} \mathrm{N} 85^{\circ} 48^{\prime} \mathrm{E}\right)$, Maure ( $\left.27^{\circ} 31^{\prime} \mathrm{N} 85^{\circ} 45^{\prime} \mathrm{E}\right)$, Chukha $\left(27^{\circ} 32^{\prime} \mathrm{N} 85^{\circ} 43^{\prime} \mathrm{E}\right)$, Maure Bhanjyang

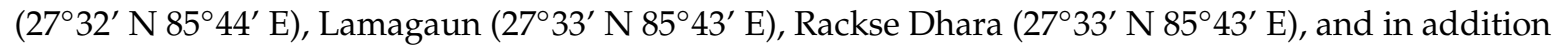
in the neighboring villages of Namo Buddha $\left(27^{\circ} 34^{\prime} \mathrm{N} 85^{\circ} 35^{\prime} \mathrm{E}\right.$, Namobuddha Municipality) and Nyaupane Sanogon ( $27^{\circ} 33^{\prime} \mathrm{N} 85^{\circ} 34^{\prime}$ E, Balthali Village Development Committee, VDC) (Figure 5).

This area is about $100 \mathrm{~km}$ far from Kathmandu and its villages are mainly occupied by the Tamang community. Although this rural area is not too far from the city centers, people living here are very deprived of basic infrastructures and facilities. Many people are illiterate and therefore the major portion of population is involved in agriculture, which is mostly subsistence farming. Some people are engaged in tourism industry as porters and guides, like drivers or other occupation. Since educational facilities for children are lacking and parents often consider education a trivial factor in life, children are not encouraged to get an education. 


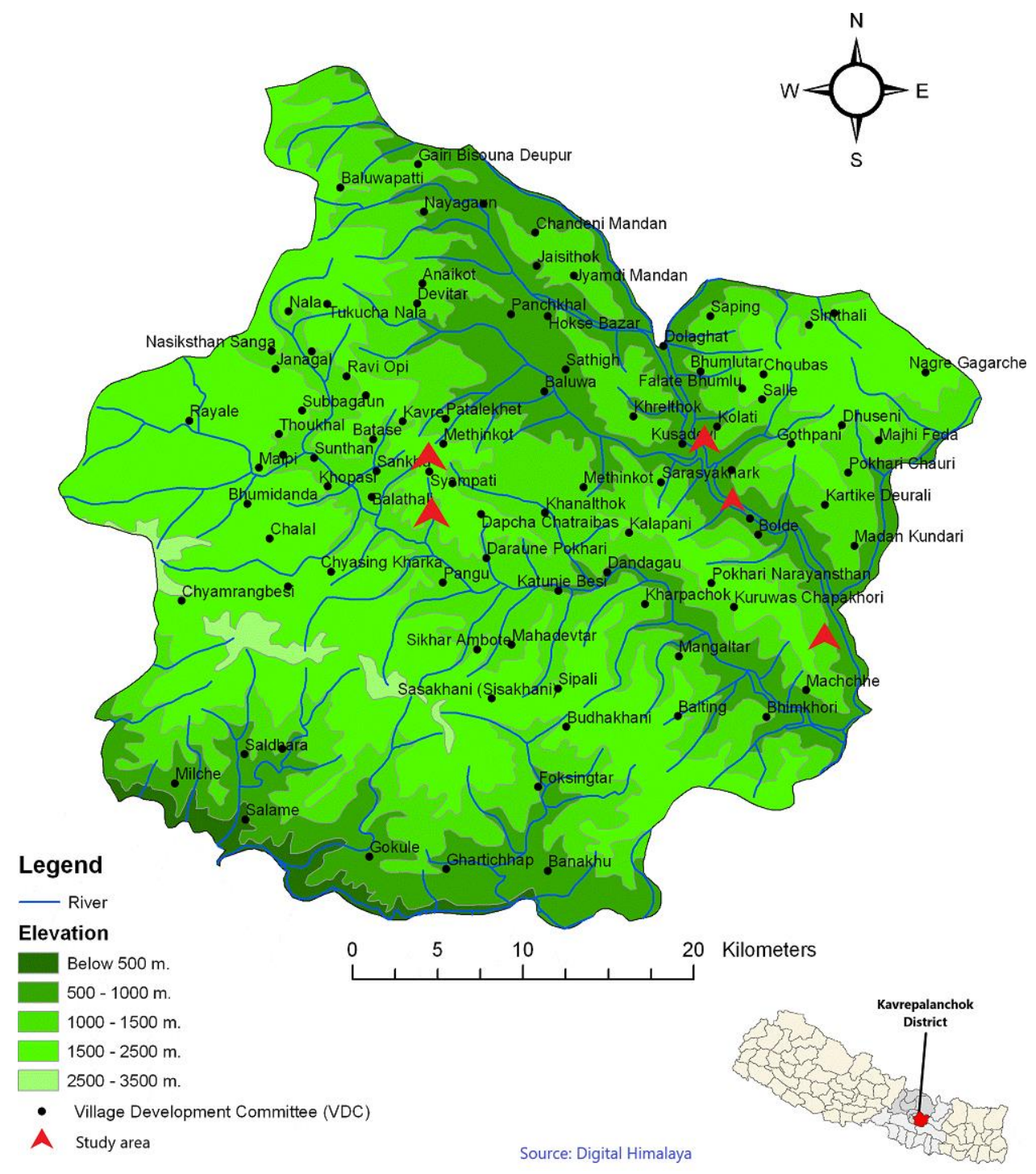

Figure 5. Map of the study area with the surveyed villages.

The criterion used in choosing the villages for this study was to have a sufficiently homogeneous survey area in terms of culture and land use. The informants belonged to the Tamang ethnic group (27 informants), and to other minor communities living in the study area, like Newar (2 informants) and Brahmin (3 informants). Tamang are one of the major Tibeto-Burmese speaking communities in Nepal, originating from Tibet. In Tibetan language "Ta" means horse and "Mang" means traders. So probably Tamang originally were horse traders. They account for 5.8\% of the total people of the country [9] and currently most of them lives in the hilly regions of Nepal, adjoining sides of the Kathmandu valley.

In the study area the Tamang is the main ethnic group, while the other groups represent a minority. In the rural villages, small Newar and Brahmin family groups have been present for a few generations, with a consequent exchange of ethnobotanical traditions. For this reason, the proportional composition of our informants reflects this ethnic distribution.

Tamang people have a rich traditional knowledge linked to plants and animals, nevertheless only a few ethnobotanical studies concerned this culture [12,16,19,25,74,75]. According to the animistic vision of Tamang, the world is populated by numerous spirits living in nature and responsible for many events of life. Evil spirits, angry ghosts (pichas), and witches (bokshi) should be the cause of balance alterations in the human organism that cause diseases. The shamans (jhankris), acting as mediators between the spiritual and the material world, have developed techniques to identify the 
evil spirits, rituals to expel them, such as mantra (secret whisper) and amulets, and herbal preparations for humans and animals [76,77]. A few informants from the study area belonged to the Newar and Brahmin ethnic groups. The Newar are the indigenous inhabitants of the Kathmandu Valley and are known for their rich artistic and cultural tradition. Their main occupations are agriculture and plant trade [58]. Brahmin (Bahuns in Nepali Language) represent one of the Hindu Nepalese castes, and not a distinguished ethnic group. They live in the central area of Nepal, occupying fertile agricultural land at the foot of the Himalayan mountain range [78].

\subsection{Field Survey and Data Collection}

The present study was carried out in the months of October and November of 2017 and 2018, after the monsoon season. During two previous study trips (2015-2016) contacts were made with the local community in order to gather information on his daily habits, work, and relationship with the natural environment. Ethnobotanical and ethnomedicinal data on plants has been collected by interviewing 32 informants from the different villages of the study area.

For the choice of the typology and number of informants we have followed the "purposive sampling" approach according to Tongco [79], a nonrandom method, where the informants are selected by virtue of knowledge and experience. In our case, such key informants are the persons recognized by the community as depository of traditional knowledge about medicinal plants. This approach allows to collect a high amount of reliable data with a low number of interviews.

Key informants (24) were traditional healers selected by the following criteria: experience (local healers and shamans); age (knowledgeable elder villagers); occupation (farmers and plant traders).The interviews were conducted in Tamang and Nepali Language with the help of a bilingual speaking local guide. The data has been collected in compliance with the rules of the World Intellectual Property Organization (WIPO) related to traditional cultural expressions [80], and of the ethical guidelines of the international society of ethnobiology (ISE) [81]. The purposes and modalities of the research were carefully communicated to the informants and a prior informed consent (PIC) was obtained [82].

Different interviews and inquiry methods were followed, according to Martin [83] and Alexiades [84]: (a) informants were asked to freely list all plants of a certain ethnobotanical interest, with special attention to plants used for medicinal purposes (free listing); (b) healers and shamans were accompanied on their excursions in search of medicinal plants and followed during the healing ceremonies and herbal remedies preparation (walk-in-the-woods and participant observation). Some difficulties have been found in interviews with shamans because of the belief that revealing the medicinal properties of a plant deprives it of the therapeutic efficacy; (c) samples of plants were shown to the informants, asking them to identify species of ethnobotanical interest (specimen display); (d) small groups of people were interviewed about their ethnobotanical knowledge using the specimen display method (group interviews).

All information was collected through semi-structured questionnaires, including questions on the informants (gender, age, ethnic group, occupation, educational level, birth place, residence place, interview place, etc.), and the plants (local name, growth form, habitat, parts used, uses, preparation and routes of administration of herbal medicine). Plant specimens were collected and partly identified in the field with the help of local guides $[58,85,86]$, and partly by one of us in the laboratory (RPC). The set of plant specimens was deposited in the Tribhuvan University Central Herbarium (TUCH), Nepal, with voucher numbers [87]. Plant nomenclature follows Plant of the World [88].

\subsection{Quantitative Analysis}

The collected data include plant species name, family, local name, altitude, location, voucher specimen number, parts used and ethnomedicinal uses. The data were then processed in ethnobotanical indices: Fic (informant consensus factor), FL (fidelity level), RFCs (relative frequency of citation), as followed. 


\subsubsection{Informants Consensus Factor (Fic)}

Informants consensus factor was calculated in order to find out the homogeneity in the information given by informants. This index is calculated for each ailment category with the following formula $[89,90]$.

$$
\text { Fic }=\left(\mathrm{N}_{\mathrm{ur}}-\mathrm{N}_{\mathrm{t}}\right) /\left(\mathrm{N}_{\mathrm{ur}}-1\right)
$$

where $\mathrm{N}_{\mathrm{ur}}$ is the number of use reports in a particular illness category, and $\mathrm{N}_{\mathrm{t}}$ the number of taxa or species used to treat that particular category. A high Fic value indicates the agreement among the informants on the use of taxa for a certain disease category.

\subsubsection{Fidelity Level (FL)}

The fidelity level (FL) is the percentage of informants claiming the use of a certain plant for the same major purpose, and is calculated according to the following formula [84,91]:

$$
\mathrm{FL}=\left(\mathrm{N}_{\mathrm{p}} / \mathrm{N}\right) \times 100
$$

where $\mathrm{N}_{\mathrm{p}}$ is the number of informants that claim the use of a plant species to treat a particular disease, and $\mathrm{N}$ the number of informants that use the same plant as a medicine to treat any disease.

\subsubsection{Relative Frequency of Citation (RFCs)}

This index is used to determine the local importance of each species in the study area. The formula used, according to Tardio and Pardo-de-Santayana [92] is:

$$
\mathrm{RFCs}=\mathrm{FCs} / \mathrm{N}
$$

where FCs is the number of informants that cites the use of a plant species, and $\mathrm{N}$ the total number of informants.

\section{Conclusions}

The present study shows that the ethnic community, living in rural areas of the Kavrepalanchok District, still retains a rich traditional knowledge of medicinal plants which are an important source for primary health care. In fact, although some allopathic medicines are available in government "health posts", most indigenous peoples rely on traditional local healers and shamans for their primary health care needs. Despite the close relationship with wilderness in this area, we have observed that this heritage is at risk. Young people are generally attracted to urban and Western lifestyles, and sometimes do not fully understand the value of traditional knowledge. Our data could be of help to the people of the rural municipalities of this area in order to plan bioconservation strategies. A recent example in the Temal region concerns an endemic species of handicraft interest, Ziziphus budhensis, which is cultivated and traded for Buddhist rosaries.

Similarly, the plants for which we have found novel therapeutic uses could be subjected to pharmacognostic investigation and cultivated in dismissed agricultural lands, turning them into a source of income and valorisation of the territory.

Therefore, the uses of medicinal plants in this area need to be explored and documented before oral traditions are lost forever. The active involvement of local populations in the valorisation, conservation, and management of medicinal plants will encourage future projects aimed at the sustainable development of the biological and cultural diversity of these rural areas of Nepal.

Author Contributions: Conceptualization: G.A., L.C.; methodology and investigations, G.A., L.C., R.P.C., M.M.; writing-original draft preparation, G.A., L.C.; supervision, L.C., M.M. All authors have read and agreed to the published version of the manuscript. 
Funding: G.A. is the recipient of a Miur PhD scholarship: XXXIII Course STAT-Distav, University of Genoa, Italy. The cultural association "In Cammino" (Piazza dei Cappuccini, 1, 16122 Genova, Italy) has provided a partial funding to the expenses incurred in Nepal.

Acknowledgments: Special thanks are due to the informants of Kavrepalanchok District (Central Nepal) and to our local guide Rajesh Lama Tamang and his team.

Conflicts of Interest: The authors declare no conflict of interest.

\section{References}

1. WHO Global Report on Traditional and Complementary Medicine 2019; WHO: Geneva, Switzerland, 2019.

2. Adhikari, M.; Thapa, R.; Kunwa, R.M.; Devkota, H.P.; Poudel, P. Ethnomedicinal Uses of Plant Resources in the Machhapuchchhre Rural Municipality of Kaski District, Nepal. Medicines 2019, 6, 69. [CrossRef] [PubMed]

3. United Nations, Department of Economic and Social Affairs, Population Division. World Population Prospects 2019. 2019. Available online: http://creativecommons.org/licenses/by/3.0/igo/ (accessed on 6 September 2019).

4. The World Bank Data. Rural Population. Available online: http://data.worldbank.org/indicator/SP.RUR. TOTL.ZS (accessed on 17 September 2019).

5. WHO. World Health Statistics 2010. Available online: http://who.int/gho (accessed on 16 September 2019).

6. Aryal, K.K.; Dhimal, M.; Pandey, A.; Pandey, A.R.; Dhungana, R.; Khaniya, B.N.; Mehta, R.K.; Karki, K.B. Knowledge Diversity and Healing Practices of Traditional Medicine in Nepal; Nepal Health Research Council: Kathmandu, Nepal, 2016. [CrossRef]

7. Press, J.R.; Shrestha, K.K.; Sutton, D.A. Annotated Checklist of the Flowering Plants of Nepal; Natural History Museum: London, UK, 2000.

8. Gaire, B.P.; Subedi, L. Medicinal plant diversity and their pharmacological aspects of Nepal Himalayas. Pharmacogny J. 2011, 3, 6-17. [CrossRef]

9. National Population and Housing Census (NPHC) 2011; Central Bureau of Statistics: Kathmandu, Nepal, 2012.

10. Niroula, G.; Singh, N.B. Religion and Conservation: A Review of Use and Protection of Sacred Plants and Animals in Nepal. J. Inst. Sci. Technol. 2015, 20, 61-66. [CrossRef]

11. Kunwar, R.M.; Bussmann, R.W. Ethnobotany in the Nepal Himalaya. J. Ethnobiol. Ethnomed. $2008,4,24$. [CrossRef]

12. Bhattarai, N.K. Herbal Folk Medicines of Kabhrepalanchok District, Central Nepal. Int. J. Crude Drug Res. 1990, 28, 225-231. [CrossRef]

13. Manandhar, N.P. Medicinal plant lore of Tamang tribe of Kabhrepalanchok District, Nepal. Econ. Bot. 1991, 45, 58-71. [CrossRef]

14. Chhetri, R.B.; Gauchan, D.P. Traditional knowledge in fruit pulp processing of Lapsi in Kavre district. Indian J. Trad. Knowl. 2007, 6, 46-49.

15. Pratik, A.; Roshan, K.C.; Kayastha, D.; Thapa, D.; Shrestha, R.; Shrestha, T.M.; Gyawali, R. Phytochemical Screening and Anti-Microbial Properties of Medicinal Plants of Dhunkharka Community, Kavrepalanchowk, Nepal. Int. J. Pharm. Biol. Arch. 2011, 2, 1663-1667.

16. Malla, B.; Chhetri, R.B. Indigenous knowledge on ethnobotanical plants of Kavrepalanchowk District. Kathmandu Univ. J. Sci. Eng. Technol. 2009, 5, 96-109.

17. Shah, S.; Lamichhane, D. Documentation of Indigenous Knowledge on plants used by Tamang Community of Kavrepalanchok District, Central Nepal. J. Plant Res. 2017, 15, 45-51.

18. Bhattarai, N.K. Ethnobotanical studies in Central Nepal: The ceremonial plants food. Contrib. Nepalese Stud. 1989, 16, 35-41.

19. Shrestha, P.M.; Dhillion, S.S. Medicinal plant diversity and use in the highlands of Dolakha district, Nepal. J. Ethnopharmacol. 2003, 86, 81-96. [CrossRef]

20. Tamang, G. An ethnobiological study of Tamang people. Our Nat. 2003, 1, 37-41. [CrossRef]

21. Kunwar, R.M.; Nepal, B.K.; Sigdel, K.P.; Balami, N. Contribution to the Ethnobotany of Dhading District, Central Nepal. Nepal J. Sci. Technol. 2006, 7, 65-69. [CrossRef]

22. Joshi, K.; Joshi, A.R. Ethnobotanical Studies on Some Lower Plants of the Central Development Region, Nepal. Ethnobotanical Leaflets 2008, 12, 832-840. 
23. Bhattarai, S.; Chaudhary, R.P.; Taylor, R.S. Ethno-medicinal Plants Used by the People of Nawalparasi District, Central Nepal. Our Nat. 2009, 7, 82-89. [CrossRef]

24. Joshi, K.; Joshi, R.; Joshi, A.R. Indigenous knowledge and uses of medicinal plants in Macchegaun Nepal. IJTK 2011, 10, 281-286.

25. Thapa, S. Medico-ethnobotany of Magar Community in Salija VDC Parbat district, Central Nepal. Our Nat. 2012, 10, 176-190. [CrossRef]

26. Luitel, D.R.; Rokaya, M.B.; Timsina, B.; Munzbergovà, Z. Medicinal plants used by the Tamang community in the Makawanpur district of Central Nepal. J. Ethnobiol. Ethnomed. 2014, 10, 5. [CrossRef]

27. Tamang, R.; Sedai, D.R. Documentation of Ethnomedicinal Knowledge on Plant Resources Used by Baram Community in Arupokhari VDC, Gorkha District, Central Nepal. Bull. Dept. Plant Res. 2016, 38, 60-64.

28. Bhattarai, S.; Chaudhary, R.P.; Quave, C.L.; Taylor, R.S.L. The use of medicinal plants in the transhimalayan arid zone of Mustang district, Nepal. J. Ethnobiol. Ethnomed. 2010, 6, 4. [CrossRef] [PubMed]

29. Shrestha, N.; Shrestha, S.; Koju, L.; Shrestha, K.K.; Wang, Z. Medicinal plant diversity and traditional healing practices in eastern Nepal. J. Ethnopharmacol. 2016, 192, 292-301. [CrossRef] [PubMed]

30. Bechan, R.; Prasad, K.D. Present status of traditional healthcare system in Nepal. Int. J. Res. Ayurveda Pharm. 2011, 2, 876-882.

31. Bhattarai, K.R. Ethnobotanical study of plants used by Thami community in Ilam District, eastern Nepal. Our Nat. 2018, 16, 55-67. [CrossRef]

32. Balami, N.P. Ethnomedicinal uses of plants among the Newar Community of Pharping Village of Kathmandu District, Nepal. Tribhuvan Univ. J. 2004, 24, 13-19. [CrossRef]

33. Saratha, V.; Pillai, S.I.; Subramanian, S. Isolation and characterization of lupeol, a triterpenoid from Calotropis gigantea latex. Int. J. Pharm. Sci. Rev. Res. 2011, 10, 54-57.

34. Akindele, A.J.; Ibe, I.F.; Adeyemi, O.O. Analgesic and antipyretic activities of Drymaria cordata (Linn.) Willd (Caryophyllaceae) extract. Afr. J. Tradit. Complement. Altern. Med. 2012, 9, 25-35. [CrossRef]

35. Kuganesan, A.; Thiripuranathar, G.; Navaratne, A.N.; Paranagama, P.A. Antioxidant and anti-inflammatory activities of peels, pulps and seed kernels of three common mango (Mangifera indica L.) varieties in Sri Lanka. Int. J. Pharm. Sci. Res. 2017, 8, 70-78.

36. Raghavendra, M.P.; Satish, S.; Raveesha, K.A. Phytochemical analysis and antibacterial activity of Oxalis corniculata; a known medicinal plant. my Sci. 2006, 1, 72-78.

37. Wan, J.Y.; Rong Jiang, X.G.; Zhang, Z.; Zhang, L. Antipyretic and Anti-inflammatory Effects of Asiaticoside in Lipopolysaccharide-treated Rat through Up-regulation of Heme Oxygenase-1. Phytother. Res. 2012, 27, 1136-1142. [CrossRef]

38. Donipati, P.; Sreeramulu, S.H. Preliminary Phytochemical Screening of Curcuma caesia. Int. J. Curr. Microbiol. Appl. Sci 2015, 4, 30-34.

39. Gao, C.-K.; Gao, J.; Ma, R.-L.; Xu, X.-X.; Huang, P.; Ni, S.-D. Research on analgesic and anti-inflammatory and invigorate circulation effects of total saponins of Achyranthes. Anhui Med. Pharm. J. 2003, 7, 248-249.

40. Tamang, R.; Thakur, C.K.; Koirala, D.R.; Chapagain, N. Ethno-medicinal Plants Used by Chepang Community in Nepal. J. Plant Res. 2017, 15, 21-30.

41. Acharya, R.; Acharya, K.P. Ethnobotanical study of medicinal plants used by Tharu community of Parroha VDC, Rupandehi District, Nepal. Sci. World 2009, 7, 80-84. [CrossRef]

42. Aarti, C. A review on pharmacological and biological properties of Calotropis gigantea. Int. J. Recent Sci. Res. 2014, 5, 716-719.

43. Chopra, R.N.; Nayar, S.L.; Chopra, I.C. Glossary of Indian Medicinal Plants (Including the Supplements); CSIR: New Delhi, India, 1986.

44. Bhattarai, K.R. Ethnomedicinal Practices of the Lepcha Community in Ilam, East Nepal. J. Plant Res. 2017, 15, $31-44$.

45. Bantawa, P.; Rai, R. Studies on ethnomedicinal plants used by traditional practitioners, Jhankri, Bijuwa and Phedangma in Darjeeling Himalaya. Nat. Prod. Rad 2009, 8, 537-541.

46. Paudyal, S.K.; Ghimire, G. Indigenous Medicinal Knowledge among Tharus of Central Dang. A note on gastro-intestinal diseases. In Proceedings of the two-days conference on Gender, Education and Development, and Indigenous Knowledge and Health Practices, Kathmandu, Nepal, 21-22 December 2005; CERID: Balkhu, Nepal, 2006; Volume 22, pp. 98-105. 
47. Divakar, M.C.; Lakshmi Devi, S.; Panayappan, L. Pharmacognostical Investigation of Wrightia Arborea Leaf. J. Chem. Pharm. Res. 2010, 2,117-121.

48. Ngan, P.T. A Revision of the Genus Wrightia (Apocynaceae). Ann. Mo. Bot. Gard. 1965, 52, $114-175$. [CrossRef]

49. Khyade Mahendra, S.; Vaikos Nityanand, P. Pharmacognostic evaluation of Wrightia arborea (Densst.) Mabb. Int. J. Res. Ayurveda Pharm. 2014, 5, 89-94. [CrossRef]

50. Pandey, M.R. Use of Medicinal Plants in Traditional Tibetan Therapy System in Upper Mustang, Nepal. Our Nat. 2006, 4, 69-82. [CrossRef]

51. Houël, E.; Stien, D.; Bourdy, G.; Deharo, E. Quassinoids: Anticancer and antimalarial activities. In Natural Products: Phytochemistry, Botany and Metabolism of Alkaloids, Phenolics and Terpenes; Ramawat, K., Mérillon, J.M., Eds.; Springer: Berlin/Heidelberg, Germany, 2013; pp. 3775-3802.

52. World Health Organization. Regional Office for the Western Pacific. Medicinal Plants in the Republic of Korea: Information on 150 Commonly Used Medicinal Plants; WHO Regional Office for the Western Pacific: Manila, Philippines, 1998; pp. 204-205.

53. Singh, B. Arboreal Flora of Nokrek Biosphere Reserve, Meghalaya. Ph.D. Thesis, Gauhati University, Guwahati, India, 2011.

54. Santhosh, C.R.; Shridhar, N.B.; Narayana, K.; Ramachandra, S.G.; Dinesh, S. Studies on the luteolytic, oestrogenic and follicle-stimulating hormone like activity of plant Rhaphidophora pertusa (Roxb.). J. Ethnopharmacol. 2006, 107, 365-369. [CrossRef] [PubMed]

55. Dash, P.K.; Sahoo, S.; Bal, S. Ethnobotanical Studies on Orchids of Niyamgiri Hill Ranges, Orissa, India. Ethnobot. Leafl. 2008, 12, 70-78.

56. Suneetha, J.; Prasanthi, S.; Ramarao Naidu, B.V.A.; Seetharami Reddi, T.V.V. Indigenous phytotherapy for bone fractures from Eastern Ghats, Andhra Pradesh. Indian J. Tradit. Knowl. 2011, 10, 550-553.

57. Chandra, S.; Rawat, D.S. Medicinal plants of the family Caryophyllaceae: A review of ethno-medicinal uses and pharmacological properties. Integr. Med. Res. 2015, 4, 123-131. [CrossRef]

58. Manandhar, N.P. Plants and People of Nepal; Timber Press: Portland, OR, USA, 2002.

59. Rijal, A. Surviving on Knowledge: Ethnobotany of Chepang community from midhills of Nepal. Ethnobot. Res. Appl. 2011, 9, 181-215. [CrossRef]

60. Sandhya Sri, B.; Seetharami Reddi, T.V.V. Traditional phyto-antidotes used for snakebite by Bagata tribe of Eastern Ghats of Visakhapatnam district, Andhra Pradesh. Int. Multidiscip. Res. J. 2011, 1, 42-45.

61. Murugammal, S.; Ilavarasan, R. Phytochemical standardization of the leaves of a medicinal plant Cipadessa baccifera Roth Miq. J. Pharm Res. 2016, 10, 609-613.

62. Uniyal, S.K.; Singh, K.N.; Jamwal, P.; Lal, B. Traditional use of medicinal plants among the tribal communities of Chhota Bhangal, Western Himalaya. J. Ethnobiol. Ethnomed. 2006, 2, 14. [CrossRef]

63. Hassan, A.U.; Ajaib, M.; Anjum, M.; Siddiqui, S.Z.; Malik, N.Z. Investigation of Antimicrobial and Antioxidant Activities of Cirsium wallichii DC. Biologia (Pakistan) 2016, 62, 297-304.

64. DeFilipps, R.A.; Krupnick, G.A. The medicinal plants of Myanmar. PhytoKeys 2018, 102, 1-341. [CrossRef]

65. Wang, Y.Y.; Tian, J.M.; Zhang, C.C.; Luo, B.; Gao, J.M. Picrotoxane Sesquiterpene Glycosides and a Coumarin Derivative from Coriaria nepalensis and Their Neurotrophic Activity. Molecules 2016, 21, 1344. [CrossRef]

66. Yadav, M.; Gulkari, V.D.; Wanjari, M.M. Bryophyllum pinnatum leaf extracts preventi formation of renal calculi in lithiatic rats. Anc. Sci. Life 2016, 36, 90-97. [CrossRef]

67. Singh, A.G.; Hamal, J.P. Traditional phytotherapy of some medicinal plants used by Tharu and Magar communities of Western Nepal, against dermatological disorders. Sci. World 2013, 11, 81-89. [CrossRef]

68. Bhattarai, S.; Tamang, R. Medicinal and aromatic plants: A synopsis of Makawanpur district, central Nepal. Int. J. Ind. Herbs Drugs 2017, 2, 6-15.

69. Grover, J.K.; Yadav, S.P. Pharmacological actions and potential uses of Momordica charantia: A review. J. Ethnopharmacol. 2004, 93, 123-132. [CrossRef]

70. Ojewole, J.A.; Adewole, S.O.; Olayiwola, G. Hypoglycaemic and hypotensive effects of Momordica charantia Linn. (Cucurbitaceae) whole plant aqueous extract in the rat. Cardiovasc. J. S. Afr. 2006, 17, 227-232. [PubMed]

71. Verma, R.; Balaji, B.S.; Dixit, A. Phytochemical analysis and broad spectrum antimicrobial activity of ethanolic extract of Jasminum mesnyi Hance leaves and its solvent partitioned fractions. Bioinformation 2018, 14, 430-438. [CrossRef] [PubMed] 
72. Acharya, K.P.; Rokaya, M.B. Ethnobotanical survey of medicinal plants traded in the streets of Kathmandu Valley. Sci. World 2005, 3, 44-48.

73. Bajracharya, D.M. Phyto-geography of Nepal Himalaya. Tribhuvan Univ. J. 1996, 19, 57-76. [CrossRef]

74. Toffin, G.; Wiart, J. Recherches sur l'Ethnobotanique des Tamang du Massif du Ganesh Himal (Népal central): Les plantes non cultivées. J. Agric. Tradit. Bot. Appl. 1985, 32, 127-175. [CrossRef]

75. Shrestha, P. Contribution to the Ethnobotany of the Tamangs of Kathmandu Valley. Contrib. Nepalese Stud. 1988, 15, 247-266.

76. Peters, L.G. Tamang Shamans. An. Ethnopsychiatric Study of Ecstasy and Healing in Nepal; Nirala Publications: New Delhi, India, 2007.

77. Khatry, P.K. The Nepalese Traditional Concepts of Illness and Treatment. DADA Riv. Antropol. Postoglob. 2011, 1, 45-54.

78. Fisher, J.F. Brahman and Chhetri of Nepal. Encyclopedia of World Cultures. Available online: https://www.encyclopedia.com/humanities/encyclopedias-almanacs-transcripts-and-maps/brahman-andchhetri-nepal (accessed on 19 April 2020).

79. Tongco, M.D. Purposive Sampling as a Tool for Informant Selection. Ethnobot. Res. Appl. 2007, 5, 147-158. [CrossRef]

80. WIPO. WIPO Intellectual Property Handbook: Policy, Law and Use, 2nd ed.; WIPO Publication: Geneva, Switzerland, 2004.

81. International Society of Ethnobiology. ISE Code of Ethics (with 2008 Additions). Available online: http://ethnobiology.net/code-of-ethics/ (accessed on 30 October 2019).

82. Singh, R.K.; Singh, K.P.; Turner, N.J. A special note on Prior Informed Consent (PIC). Why are you asking our gyan (knowledge) and padhati (practice)? Ethics and prior informed consent for research on traditional knowledge systems. Indian J. Tradit. Knowl. 2013, 12, 547-562.

83. Martin, G.J. Ethnobotany. A Methods Manual; Walter, M., Ed.; Chapman \& Hall: London, UK, 1995.

84. Alexiades, M.N. Selected Guidelines for Ethnobotanical Research: A Field Manual; Alexiades, M.N., Ed.; NYBG Press: Bronx, NY, USA, 1996.

85. Joshi, K.K.; Joshi, S.D. Medicinal and Aromatic Plants Used in Nepal, Tibet and Trans-Himalayan Region; AuthorHouse: Bloomington, IN, USA, 2006.

86. Polunin, O.; Stantion, A. Flowers of Himalaya; Oxford University Press: New Delhi, India, 1999.

87. Preparation of Plant Specimens for Deposit as Herbarium Vouchers. Available online: https://www. floridamuseum.ufl.edu/herbarium/voucher.htm (accessed on 28 April 2020).

88. Plants of the World Online. Royal Botanic Gardens, Kew. Available online: http://www.plantsoftheworldonline. org/ (accessed on 30 April 2020).

89. Trotter, R.T.; Logan, M.H. Informant consensus: A new approach for identifying potentially effective medicinal plants. In Plants in Indigenous Medicine \& Diet. Biobehavioral Approaches; Etkin, N.L., Ed.; Routledge: London, UK, 1986; pp. 91-112.

90. Collins, S.; Martins, X.; Mitchell, A.; Teshome, A.; Arnason, J.T. Quantitative Ethnobotany of two East Timorese cultures. Econ. Bot. 2006, 60, 347-361. [CrossRef]

91. Andrade-Cetto, A.; Heinrich, M. From the field to the lab: Useful approaches to selecting species based on local knowledge. Front. Pharmacol. 2011, 2. [CrossRef]

92. Tardìo, J.; Pardo-De-Santayana, M. Cultural Importance Indices: A Comparative Analysis Basedon the Useful Wild Plants of Southern Cantabria (Northern Spain). Econ. Bot. 2008, 62, 24-39. [CrossRef]

(C) 2020 by the authors. Licensee MDPI, Basel, Switzerland. This article is an open access article distributed under the terms and conditions of the Creative Commons Attribution (CC BY) license (http://creativecommons.org/licenses/by/4.0/). 